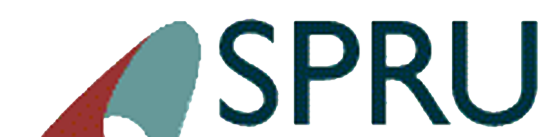

Science Policy Research Unit
Working Paper Series

SWPS 2014-12

June, 2014

\title{
Developing capabilities in the seed industry: which direction to follow?
}

Anabel Marin, Lilia Stubrin and

Patrick van Zwanenberg 


\section{SPRU Working Paper Series}

The SPRU Working Paper Series aims to accelerate the public availability of the research undertaken by SPRU-associated people of all categories, and exceptionally, other research that is of considerable interest within SPRU. It presents research results that in whole or part are suitable for submission to a refereed journal, to a sponsor, to a major conference or to the editor of a book. Our intention is to provide access to early copies of SPRU research.

\section{Editors}

Tommaso Ciarli

Daniele Rotolo

\section{Associate Editors}

Florian Kern

Paul Nightingale

Matias Ramirez

Joe Tidd \&

Carlos Sato

Maria Savona \&

Mariana Mazzucato

Andrew Stirling Transitions

Caitriona McLeish

Civil military interface

Area

Energy

\section{Contact}

T.Ciarli@sussex.ac.uk

D.Rotolo@sussex.ac.uk

F.Kern@sussex.ac.uk

P.Nightingale@sussex.ac.uk

Matias.Ramirez@sussex.ac.uk

J.Tidd@sussex.ac.uk

C.E.Y.Sato@sussex.ac.uk

M.Savona@sussex.ac.uk

M.Mazzucato@sussex.ac.uk

A.C.Stirling@sussex.ac.uk

C.A.McLeish@sussex.ac.uk

J.Lieu@sussex.ac.uk

Administrator

Jenny Lieu

\section{Disclaimer}

The works available here are the responsibility of the individual author(s) and do not necessarily represent the views of other SPRU researchers. As matters of policy and practice, SPRU does not endorse individual research contributions.

\section{Guidelines for authors}

Papers shall be submitted in pdf or Word format. They should contain a title, an abstract, and keywords. Papers should be submitted to one of the Editors, who will process them and send them to the appropriate Associate Editor. Two members of SPRU will be asked to provide a short written review within three weeks. The revised versions of the paper, together with a reply to the reviewers, should be sent to the Associate Editor, who will propose to the Editors its publication on the series. When submitting the authors should indicate if the paper has already undergone peerreviewing, in which case the Associate Editors may decide to skip internal review process.

\section{Website}

SWPS: www.sussex.ac.uk/spru/research/swps

IDEAS: ideas.repec.org/s/sru/ssewps.html 


\section{Developing capabilities in the seed industry: which direction to follow?}

Anabel Marin* Lilia Stubrin \& Patrick van Zwanenberg

Centro de Investigaciones para la Transformación (Cenit)

Callao $3533^{\circ}$ B, Ciudad de Buenos Aires (CP C1022AAD), Argentina.

\section{Working Paper}

June 2014

*Corresponding author: Conicet/Cenit Argentina. Address: Callao 353, 3er piso B - (CP 1022) Ciudad Autonóma de Buenos Aires - Argentina. Tel.: (5411) 4373-3714|(5411) 5199-6393. Email:a.i.marin@,fundcenit.org.ar

Financial support from IDRC is gratefully acknowledged, in particular from the project: Opening Up Natural Resource-Based Industries for Innovation: Exploring New Pathways for Development in Latin America.

We thank the comments received from all the participants at SIDPA, in particular Roberto Bisang who provide very useful insights in discussing the paper 


\begin{abstract}
Since the 1990s, many developing country policy makers have assumed that plant genetic engineering represents the only technological frontier in seed innovation; that it has been the leading technology for improving seeds and agricultural performance in those countries where it has been adopted; and that it is the area of biotechnology in which domestic capabilities in seed innovation should be accumulated. In this paper we challenge all those assumptions through an exploration of the role that both genetic engineering and other seed innovation techniques have played in explaining dynamism in the seed market, and wider agricultural economy, in Argentina, focusing on the case of soy. We argue that existing analyses of the impact of plant genetic engineering in Argentina either ignore the performance gains from seed innovations based on techniques other than genetic engineering or misattribute them to genetic engineering.
\end{abstract}

Our analysis, based on data of registered plant varieties, evidence of agricultural performance in Argentina, and interviews with company managers and public sector researchers, seeks to distinguish between the impacts that different approaches to seed innovation have had on the soy sector. We argue that, from the data available, non-genetic engineering seed innovations appear to have had a very significant direct effect on farm-level soy productivity, much more so than those based on genetic engineering, and that they offer just as plausible a contributing explanation for indirect effects on productivity that are normally attributed to genetic engineering. Our findings are preliminary, but they stand in stark contrast to the very widely held view that genetic engineering has played a central, transformative role in the revitalisation and internationally competitive performance of soy production in Argentina over the last two decades. They also have a number of potential implications for the allocation of resources and policy support to the seed industry, and, more generally to how technological options should be considered and assessed in strategies for developing technological capabilities.

Our analysis is framed by and contributes to an emerging body of research within the innovation literature that challenges deterministic, unidirectional approaches to analysing technological change in emerging economies.

Key Words: Agricultural biotechnology, seed industry, technological capabilities, directions of innovation, catch up, Argentina. 


\section{INTRODUCTION}

Since the early 1990s, many governments in developing countries have viewed agricultural biotechnology, and plant genetic engineering specifically, as key to raising agricultural growth and productivity (Pray and Naseem 2007), mirroring similar sentiment in Europe and the USA (Smith 2000; Commission of the European Communities 2002). There have as a consequence been major government investments in the development of capabilities related to plant genetic engineering in countries such as China, India, Brazil, Argentina, Egypt and South Africa, in an attempt to 'catch up' with what is seen as the leading technological frontier in seed innovation (Ministerio de Economía y Producción 2004; Pray and Naseem 2007; Uctu and Essop 2013). Developing countries that have permitted and encouraged the commercialisation of genetically engineered crops are described by analysts as having enabled huge benefits to accrue to their agricultural sectors (Brookes and Barfoot 2009; Trigo et al. 2010; Trigo 2011), with very substantial promise for the future (Qaim 2009).

In this paper we wish to challenge some of the assumptions underlying these views on plant genetic engineering and agricultural innovation. In particular the assumptions: a) that genetic engineering represents the only technological frontier in seed innovation; b) that it is the leading technology for improving seeds and agricultural performance in those jurisdictions where it has been adopted; and

c) that developing country governments should seek to 'catch up' in that area of biotechnology specifically. We do so by exploring critically the role that genetically engineered crops have played in explaining dynamism in the seed market, and wider agricultural economy, in Argentina, focusing on the case of soy.

Argentina was one of the first developing countries to commercialise genetically engineered, or 'transgenic' seeds, and it is now the world's third largest producer of genetically engineered crops. The country is often showcased as a highly successful early convert to the technology, on the grounds that genetically engineered seeds have delivered very considerable benefits to farmers, agricultural productivity, and overall agricultural production (Penna and Lema 2003; Trigo and Cap 2003; Ablin and Paz 2004; Trigo 2011). In fact, genetically engineered crops are not only seen as having been highly beneficial, but as playing a central, transformative role in the revitalisation and internationally competitive performance of soy and maize production in Argentina in recent years (the two principal crops for which transgenic seeds are available). This is a widely shared view, articulated by agricultural economists, the media, and the Argentinean government. (Trigo and Cap 2003; Bisang 2011; Campos Motta 2013; Ministerio de Economía y Producción 2004).

Our analysis distinguishes between two innovation approaches that have been used, in Argentina as elsewhere, to improve the performance of seeds in recent decades: a genetic engineering approach, and an approach based on the longer established techniques of mutagenesis or cross-breeding. We assess how particular innovations based on those two approaches have affected seed innovation and soy production over the last two decades, drawing on evidence of registered plant varieties, agricultural performance in Argentina, and interviews with company managers and researchers from the National Institute of Agricultural Technology (INTA).

We argue that existing analyses of the impact of genetically engineered seeds fail to identify or separate the contribution of the gains in performance obtained using non-transgenic techniques either ignoring them or incorrectly attributing then to genetic engineering innovations. In our analysis, seed innovations based on non-transgenic techniques appear, from the data available, to have had a very significant effect on farm-level soy productivity, as much as or more so than innovations based on genetic engineering. Furthermore, they offer just as plausible an explanation for two other 
productivity-related phenomena commonly attributed to transgenic seed innovations: the major increase in area under soy production, and the ability to double crop soy with other plants.

One implication of our analysis is that that new evidence needs to be collected to discriminate carefully between the impact of genetic engineering and other seed innovation approaches on agricultural performance. Such evidence is important because the potential consequences of mistakenly attributing gains in agricultural performance to one seed technology rather than another are substantial. The conclusion that genetic engineering is responsible for transforming commodity crop production in Argentina has resulted, and will no doubt continue to result, in substantial state support for that technology, for example, in terms of R\&D funding, subsidies for seed firms that are trying to develop and commercialise transgenic seed varieties, and - crucially - reforms to seed intellectual property law. That policy response is very likely to entail that future pathways of seed development will be based on plant genetic engineering, regardless of the validity of the underlying justification for the performance of those technologies, in the process crowding out alternative seed innovation approaches. And yet it may be those alternative approaches (led by the domestic rather than the multinational seed industry) that have been primarily responsible for seed innovations' contribution to the performance of the Argentinean soy sector.

Our analysis is framed by and contributes to an emerging body of research within the innovation literature that challenges deterministic, unidirectional approaches to analysing technological change in emerging economies. Such mainstream approaches typically ignore the possibility that latecomer firms in developing countries that are attempting to upgrade their technological capabilities might have different technological choices available. Rather, they assume, typically, that there is only one best way of producing a product or process in any particular industrial sector, defined as those practices currently adopted by industry leaders, and that upgrading ought to proceed in that direction alone. We argue that this unidirectional model is implicit in existing analyses of the impact of plant genetic engineering on Argentinean soy production because such analyses assume, in effect, that transgenic seed innovations have been the only potentially significant improvement to seeds (hence they ignore or do not differentiate the potential impact of alternative techniques for improving seeds). But that argument is circular: the assumption that genetic engineering represents the technological frontier in seed innovation has shaped the ways in which analyses of seed technologies has been conceived and conducted, and this has led, inevitably, to the conclusion that genetic engineering has been the leading seed technology for improving agricultural performance in Argentina. We argue that a more flexible, multidirectional framework of analysis is better suited to identifying and exploring possible technological options and choices for capability development, and enables a more informed decision-making process about which of those choices might be more useful than others for meeting economic and social development objectives.

The paper is structured as follow. We first review the theoretical background to our research, highlighting the importance of thinking about within-industry technological options in potential 'catching up' strategies. Section 3 describes the data and methodology. Section 4 discusses the two main technological approaches that have been used in Argentina, and elsewhere, to improve seeds. We argue that, in principle, all existing approaches can be performed using advanced knowledge, enabling efficient innovation processes and significant innovative outputs. Section 5 briefly outlines our case study of seed innovation and the Argentinean soy sector. Sections 6 then describe mainstream accounts of the transformation of the Argentinean soy sector, that emphasise the key role played by seed genetic engineering innovations, and this is followed by our re-evaluation of that empirical evidence. We conclude with some of the implications of our account for considering alternative pathways for seed development, and technological catch up more generally, in emerging economies. 


\section{THEORETICAL BACKGROUND: FROM INDUSTRY CHOICESTO TECHNOLOGY CHOICES}

We are used to thinking about technological change in developing countries in a deterministic, unidirectional way. Typically, the assumption is that trajectories of technological progress have already been mapped out by prior innovation by leading firms in the advanced industrial economies. 'Latecomer' firms in developing countries are seen as located somewhere earlier along those pathways, in terms of the technologies they use and produce, but able, in principle at least, to acquire the capabilities to 'catch up' along those existing pathways and narrow the gap with the technological best practices achieved by global industry leaders (Bell, 2010).

Underpinning this unidirectional conception of technological change is a large body of work in innovation studies that emphasises how technological change is, much of the time, a cumulative, path dependent phenomenon. Existing bodies of knowledge, the template of techniques and technological systems to be improved, and firms' shared routines (e.g. assumptions about what is technically feasible and potentially profitable) constitute a 'technological paradigm', in Dosi's terminology, that shapes and constrains the search for technological variants by firms. Innovation thus tends to be channeled in particular directions, giving rise to bounded 'trajectories' of technological change. Such path dependency is further reinforced by the fact that the technological approaches characteristic of progress along any particular trajectory tend to exhibit dynamic increasing returns, as a result of learning and scale economies. One important consequence of these processes is that in any particular industry, there is, at least most of the time, only one or very few competitive technological approaches to solving a problem (Dosi and Nelson 2009). ${ }^{1}$

As latecomer firms in developing countries develop their technological capabilities, the assumption, typically, given this framework, is that they have little choice but to 'upgrade' their production techniques along the same technological path previously developed and pursued by industry leaders. ${ }^{2}$ (Lall 1987; Hobday 1995; Kim 1998) Questions about the choice of technologies and direction of technological change within any particular industrial sector are rarely asked, since there is assumed to be little effective agency over such matters.

A number of factors are nevertheless beginning to alter the broader socio-economic contexts in which this deterministic conception of technological change in developing countries developed. In particular, changes in the world economy are prompting a more significant role for less advanced countries in technological development than has historically been the case These changes include: i)

\footnotetext{
${ }^{1}$ Within this model, established, institutionally embedded, ways of doing things may nevertheless sometimes be severely disrupted, for example, where radical new knowledge ( $c f$ a new technological paradigm) opens up the possibility of creating alternative, superior ways of solving problems. The argument is that whilst competing technological solutions may be available at such times, markets and other aspects of the selection environment will favour one of the contending new technological approaches and indirectly the firms that produce them - and the knowledge and routines that those firms embody. Surviving firms in a sector will thus tend to share 'technological paradigms', and a new trajectory of technological change will emerge.

${ }^{2}$ Within this framework, latecomer firms, and developing country markets and institutions more generally, not been seen as playing an active role in shaping 'the' pathways followed by particular industries. This is because the production of new knowledge has occurred, to a very significant degree, in the advanced industrialized countries, whilst the selection environments for new technologies (e.g. the markets for most world production, as well as non-market aspects such as regulations and standards) are also mainly found within, or have been imposed globally by, the advanced economies. Instead latecomer firms are seen, initially at any rate, as imitators and adopters of vintage technologies that have been shaped by the earlier knowledge, institutional and market dynamics in more technologically advanced country contexts.
} 
domestic markets that are growing faster than those in the advanced countries; (ii) new information technologies that are facilitating both the diffusion of new scientific and applied knowledge between countries and a more decentralised, networked approach within MNCs to solving problems - that includes their developing country subsidiaries; and (iii) a segmentation of markets, as the Fordist, standardised production model gives way to greater diversity of techniques, products and markets (Perez, 2010; Marin et al, forthcoming; Morris et al, 2010). Furthermore, in the natural resources sector, which is of considerable importance for most developing countries, opportunities for innovation have been increasing markedly, but technological solutions usually need to be local in nature, given physical and biological variability.

Empirically, we see that some emerging economies, such as China and India, have begun to develop unique products and technologies aimed at mass markets in developing countries, such as cars, electricity free refrigerators, and cheap laundry soaps and detergents (Kaplinsky 2011). Lim and Lee (2001) have shown how some Korean electronics firms not only upgraded their technological capabilities along existing trajectories of technological development, but also engaged in pathcreating activities, pursuing a qualitatively different direction of technological development to that previously created by global technology leaders. Similarly, Figuereido (2010) showed how Brazilian pulp and paper firms have created their own pathways of technological change.

Within the innovation literature approaches that link sociological perspectives on technological change with those from evolutionary economics - such as the 'quasi-evolutionary' approach of Rip and Schot, and a later literature on 'socio-technical transitions', provide new more interesting insights than mainstream innovation studies for analysing technology choices and these emerging issues of path creation in developing country contexts. Those approaches typically draw attention to the plurality of possible technological solutions available, and the social agency involved in technological path creation, for example, by stressing how policy institutions and political commitments also form an important part of selection environments, and how firms and other actors may actively seek to shape selection environments as to increase the chances of survival of their innovative variants (Kemp et al. 1998; Smith et al. 2005). We build on this attention to social agency in technological change to reframe the typical question in developing countries research on technological change. Instead of asking 'Which industrial sectors to select, and how to encourage capabilities along existing technological trajectories within these industries?' we ask: 'Are there technological options available within an industry? How many are there? Why does one option get selected over another? Which ones are more adequate than others for the development purposes of the country? How should these options be evaluated? And how might particular options and directions of change be encouraged and fostered?

\section{DATA AND METHODOLOGY}

The empirical sections of this paper address different questions and draw on different methodological approaches and sources of data.

Section 4 distinguishes between and discusses different technological approaches used to develop seeds in Argentina. To do so we draw on both published scientific and policy documents and evidence that we have collected from interviews with both seed company breeders based in Argentina (Don Mario, Nidera and Advanta) and researchers from the National Institute of Agricultural Technology (INTA).

Section 5 summarises the main characteristics of the Argentinean seed market, based on market data (i.e. market share, types of organization involved in seed production and commercialization) and 
provides a discussion of market and intellectual property regulations that affect transgenic seeds and seeds produced using non-transgenic methods, based on secondary data.

Section 6 analyses the contribution of different seed innovation approaches to soy performance in Argentina, and is divided into three parts. The first part describes the performance of soy-production and seed innovation in Argentina over the last two decades. Information on agricultural performance was obtained from the Argentinean Ministry of Agriculture, covering the evolution of soy production, yields and the area under cultivation. Information on innovation activity in the seed sector was obtained from plant registration data compiled by the National Registry of Property of Varieties (RNPC). Plant breeders that wish to protect their varieties under the intellectual property rights system for seeds must apply for registration. The RNPC contains information, for each plant variety, on the name of the breeder, the year in which property rights were requested, the country of origin of the variety, the plant variety maturity group to which it belongs, and whether or not the variety is transgenic.

The second part of section 6 re-examines the conventional explanation that glyphosate-resistant soybean is the innovation primarily responsible for the expansion and performance of soybean production in Argentina. That discussion is based on existing literature, and data on plant varieties certified by the National Seed Institute (INASE). In Argentina, as elsewhere, seeds that are traded commercially have to be certified as reaching minimum standards of genetic purity, identity and quality. We use the INASE dataset, which covers the period 1994-2011, to examine the evolution of the market share of glyphosate-resistant varieties in Argentina.

The final part of section 6 examines the importance of non-transgenic seed innovations for the performance of soy production since the introduction of transgenic varieties. Interviews with seed firms and INTA, an analysis of secondary literature, and the assessment of plant varieties evaluated by the National Network of Soybean Varieties' Assessment (RECSO) were used to identify nontransgenic soybean innovations. We also used an INTA dataset, based on an annual assessment of the main phenological and productive characteristics of commercially traded soybean plants (which covers the period 1997-2011), to identify soybean plant varieties' growth habits. We analyse to what extent the diffusion of plant varieties that have incorporated a non-transgenic innovation that changes soy plants growth habits, as well as those that are glyphosate-resistant, are related to the expansion of both land cultivated with soy and soy production in the Argentinean province of Córdoba in the period 1997-2010. We also perform a simple exercise to quantify the importance of non-transgenic seed innovations on farmers' income since 1997, and we compare this with the direct impacts of glyphosate resistance on income. Data for that exercise is drawn from the Argentinean Ministry of Agriculture and other secondary sources.

\section{TECHNOLOGY OPTIONS IN THE SEED INDUSTRY}

Seed innovation is concerned with the identification of desirable plant characteristics or 'traits' and the creation of new plant varieties or 'cultivars' that contain those traits. Traditionally, seeds have been improved by cross breeding, a technique that essentially involves choosing, from the available pool of genetic variation, individual plants that contain desirable traits, crossing them, and then selecting the progeny for the desired combinations of parental characteristics. In this way, desirable traits from one plant variety or line can be introduced into another (e.g. fungal resistance can be introduced into a high yielding crop variety). Basic selection of desirable crop variants has been carried out by farmers for thousands of years, and knowledge-intensive cross breeding for more than 
a century, resulting in an accumulation of valuable traits over time in agricultural plants. A later approach, mutagenesis, dates from the 1920s, and involves artificially increasing natural species variation by exposing an existing plant variety to chemical or physical agents in order to generate random mutants. Some of these will have desirable traits, and these can then be incorporated into conventional cross breeding programmes. The most recent approach, genetic engineering uses techniques to identify gene sequences (that code for certain desirable traits) and to transfer these into existing commercial plant varieties in order to create new cultivars. Where this involves the transfer of gene sequences from one species to another, the plant varieties are known as transgenic plants.

In much economic and policy commentary on seed innovation, as well as some scientific discussion, genetic engineering is represented as the superior of these three techniques: as a development that has radically altered the ways in which seeds can be improved, and that opens up opportunities in agriculture that were previously unthinkable (Royal Society et al 2000; United Nations Development Program 2001; FAO 2004). This perspective corresponds closely to the theoretical set of assumptions in innovation studies, discussed in the previous section, that views technological progress in developing economies as unidirectional; following a fixed pathway mapped out previously by country and industry technological leaders. A caricature of such a pathway (see Figure 1), and one that can be found explicitly in at least some scientific commentary on the evolution of plant breeding techniques, ${ }^{3}$ might begin with the selection of high performing variants and basic cross breeding, based on the tacit skills of farmers, before progressing to more sophisticated cross breeding by skilled agronomists, drawing on knowledge of Mendelian principles of heredity, and eventually to the highly knowledge-intensive ability to create transgenic organisms by inserting genetic material from one species to another. At that 'technological frontier' sit a handful of North American, European and Chinese firms as well as some public sector organisations, mainly in the advanced economies. ${ }^{4}$

\footnotetext{
${ }^{3}$ For example, Prem Jauhar (2006), a plant geneticist with the US Department of Agriculture, provides a similar graphical representation to Figure 1. He depicts plant breeding as having moved through three stages of progressively higher evolution: from the 'ancient art of plant breeding' to 'science based plant breeding (through chromosome mediated gene transfers)' and finally to 'molecular plant breeding (genetic transformation through direct gene transfers)'.

${ }^{4}$ It is important to note that neither mutagenesis nor genetic engineering can replace cross breeding entirely. Both approaches rely on existing seed varieties in which to either insert gene sequences, or breed in new traits, and those existing varieties are themselves the culmination of centuries of traditional cross breeding (See Figure 1) Nevertheless, as techniques for the identification and/or creation of new traits (as opposed to the creation of entire new cultivars) cross breeding, mutagenesis and genetic engineering are potentially competing seed innovation approaches.
} 
Figure 1: Conventional unidirectional view of technological options for plant's innovation

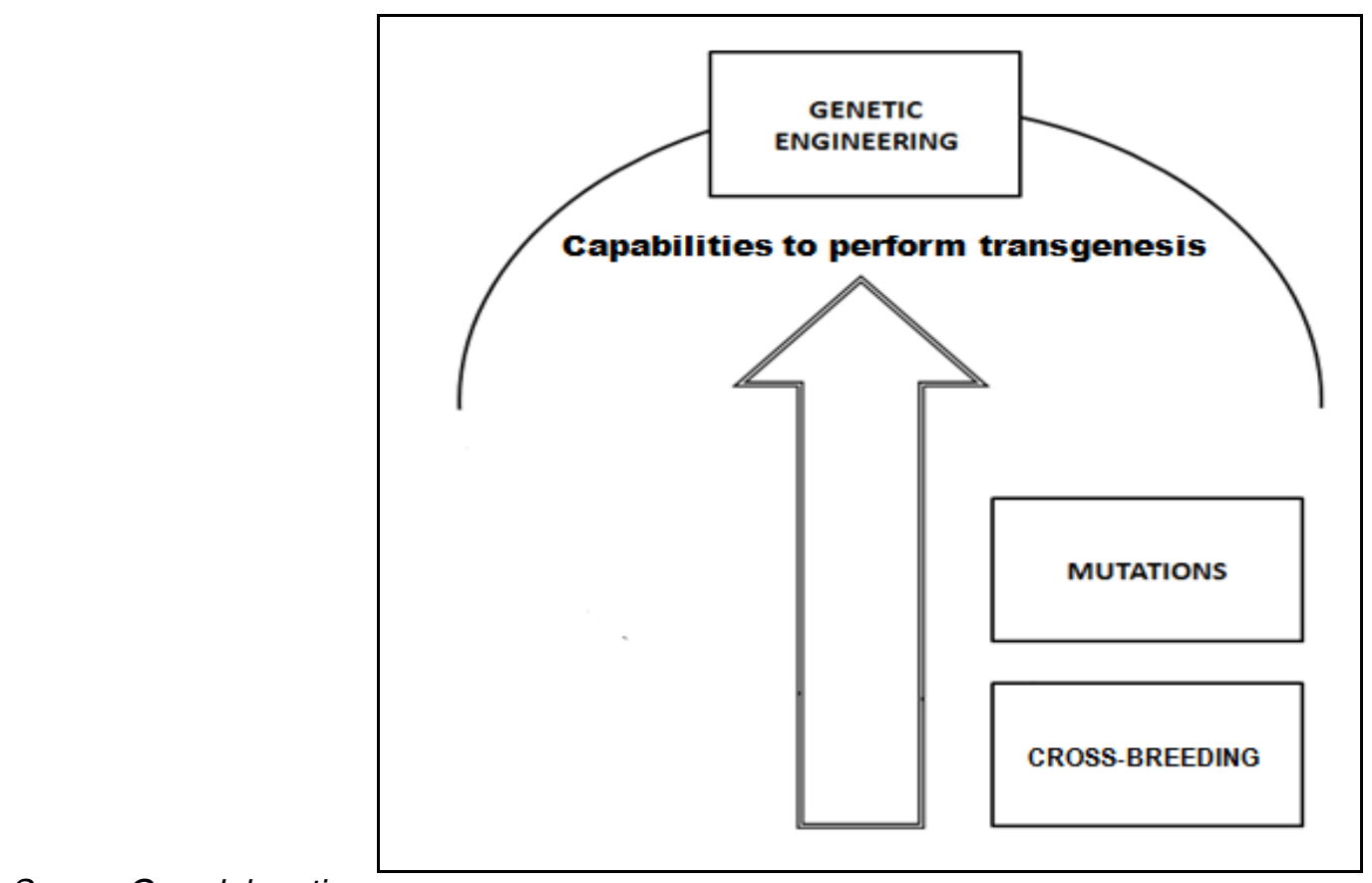

Source: Own elaboration.

The evident novelty of genetic engineering techniques, and very significant investment in the technology by some of the world largest R\&D intensive firms, no doubt contributes to the view that genetic engineering is 'the' frontier technology for seed innovation. At the same time various 'technical' justifications as to why genetic engineering techniques provide the most promising basis for future seed innovation have been, and continue to be, routinely articulated, including by some very influential scientific and international bodies (Smith 2000; Royal Society et al 2000; FAO 2004; Moose and Mumm 2008; Sense about Science 2009; Jauhar 2010). These justifications are of two types. One is that genetic engineering can improve the process of seed innovation. The claim is that it is a more precise and efficient technique for improving seeds ${ }^{5}$. The second is that the technology can improve the outcome of seed innovation. Given that genetic engineering is able to draw on genetic material beyond species boundaries, the argument is that it can be used to improve seeds and overcome agricultural production constraints in ways that would be impossible, more difficult or more costly with older techniques of plant breeding.

Both justifications deserve careful scrutiny. The first of these - that genetic engineering techniques will improve the process of seed innovation - is based, in large part, on the fact that genetic engineering is able to exploit advanced scientific knowledge in molecular biology. Yet, as many individual scientists and professional scientific associations are careful to acknowledge, the same bodies of advanced knowledge can be and are being used in cross breeding and mutagenesis, enhancing the speed and precision of innovation using those techniques too (Biochemical Society 2011). For example, the use of genomic techniques such as molecular marker assisted breeding

\footnotetext{
${ }^{5}$ For example, it is argued that with genetic engineering only desired changes to a genome are made, unlike cross-breeding and mutagenesis which produce a lot of unintended genetic changes; furthermore, it is argued that since there is no need to repeatedly recross progeny with one of the parents in order to try and get rid of undesired genetic changes, a new cultivar can be produced in far less time than with older methods
} 
significantly increases the precision and predictability of cross-breeding, and reduces the time involved in creating a new cultivar (Beddington 2010; Morrell et al. 2011; McCouch et al. 2013). The claimed advantages of genetic engineering, in terms of improved processes, are not necessarily apparent in practice (Gepts 2002).

As for the argument that genetic engineering can improve the outcome of seed innovation, it is striking how little evidence there is in support of that claim. Instead it is based largely on expectations about what the technology may be able to achieve in the future (e.g. Smith 2000). For the time being, at least, the innovative outputs from genetic engineering can often be achieved with other approaches. Thus key traits achieved by genetic engineering - for herbicide tolerance, coleopteran pest resistance, $b$-carotene enrichment and delayed ripening - have all been introduced in major food crop varieties by advanced cross breeding and mutagenesis techniques (Arundel 2001; Zamir 2008; Brumlop and Finckh 2011). Furthermore, genetic engineering techniques have not yet been able to modify complex 'quantitative' traits, such as for yield and stress resistance (that are determined by numerous interacting genes), but such traits can be modified using cross breeding techniques, especially when using advanced genomic knowledge (Fernie et al. 2006).

The only available empirical evidence in support of the claim that genetic engineering may improve the outcome of seed innovation, is the body of data, and its interpretations, indicating that genetically engineered crops have already produced very significant benefits for adopters. Yet as we shall argue, at least for soy production in Argentina, the ways in which that empirical evidence has been constructed and interpreted is circular. It assumes the very hierarchical, unidirectional model of innovation - with genetic engineering at 'the' frontier as the superior technique - that that evidence subsequently appears to justify.

Our argument is that the relative technical superiority of the three techniques for seed trait innovation, given some specified criteria for defining technical superiority, is not only unclear, and no doubt case specific, but indeterminate because the technical possibilities are not only intrinsic, but depend on the level of investment and commitment to a particular technological solution. For example, genetic variation within a particular species will be limited not only by the material degree of variation itself, but also by the investment to map and understand it. As one of our interviewees noted, the complete genetic sequence of soy has only been available since 2010 and therefore we do not yet know much about the potential for intra species modification of the soy seed. Furthermore, she noted that since soy is a self-pollinating plant (a characteristic which limits seed firms ability to persuade farmers to buy new conventionally bred seed each year) there has been little investment, thus far, in trying to understand the functional characteristics of the soy genome.

Based on these observations, we propose a more flexible, multidirectional view of the three technological approaches available for seed trait innovation (Figure 2). In this framework, each of the technological options can be performed with different levels of innovative capability. For example, within the cross breeding approach, advanced capabilities involve the performance of plant breeding using knowledge about genomic selection and the equipment necessary to exploit that knowledge, whilst basic capabilities rely only on the observation of plants' external characteristics. The latter is a longer, more costly, and uncertain (and less science intensive) process. Similarly, mutation approaches can be performed with low levels of investments and capabilities or, on the basis of world leading capabilities, involving the use of advanced molecular technology. The genetic engineering approach, on the other hand, can only be performed with an advanced level of scientific and technological capabilities. Within this framework, no particular approach is assumed, a priori, to be more or less superior; rather, in principle, all three approaches can be performed using advanced knowledge, enabling efficient innovation processes and significant innovative outputs. 
Figure 2: Multidirectional framework to understand technological options for seed trait innovation

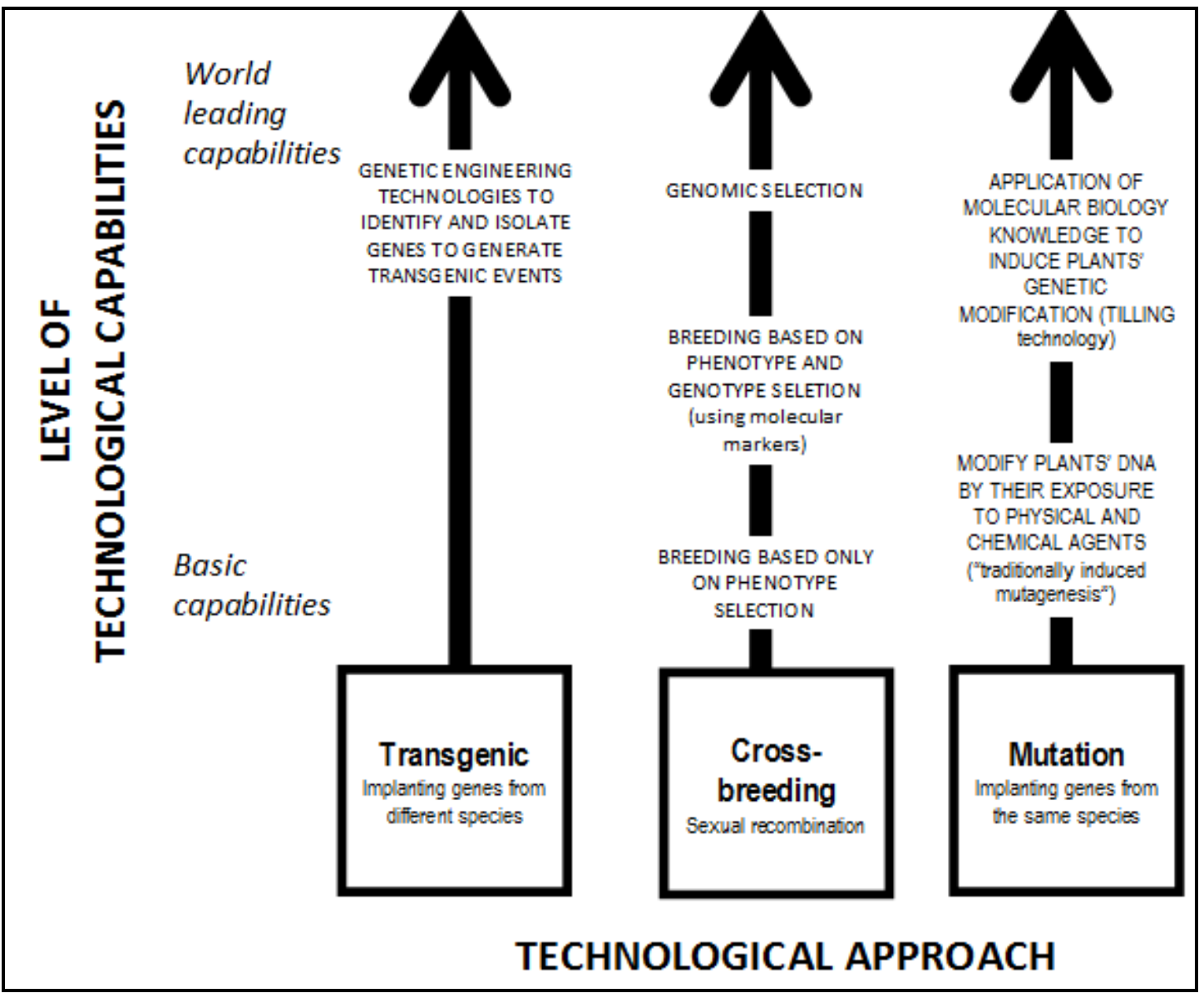

Source: Own elaboration.

These different approaches can work in complementary ways to develop new seeds, as has been the case in many circumstances. However, as noted previously, they also represent competing ways of obtaining new traits. We argue that it is important to distinguish those approaches and to consider them as alternatives because the three techniques differ markedly as regards their regulatory, market and application environments (see Table 1). Commitments to one approach rather than another may therefore have important potential consequences, amongst other things, for the structure and evolution of a national seed industry, and for the agricultural input markets and broader agricultural systems which that industry can and cannot support. 


\begin{tabular}{|c|c|c|}
\hline Potential dimensions to consider & Transgenic & Cross breeding and Mutation \\
\hline Knowledge base (1) & Scientific & Traditional and Scientific \\
\hline Type of knowledge (2) & Proprietary & Proprietary and free \\
\hline & International harmonized & Ad hoc, localised \\
\hline Regulations (3) & Very expensive & Cheap \\
\hline Potential applications (4) & Limited & Diverse \\
\hline Main private actors (5) & Large MNCs companies & $\begin{array}{l}\text { Domestic, SMEs, public agencies, } \\
\text { farmers }\end{array}$ \\
\hline Role of public institutions (6) & Limited & Often important \\
\hline Technology markets $(8)$ & Global and concentrated & Regional and disperse \\
\hline Demand (9) & $\begin{array}{l}\text { Restrictions linked to consumers' } \\
\text { awareness }\end{array}$ & Unrestricted \\
\hline Products (10) & Standarised, Private & Diversified, private and public \\
\hline $\begin{array}{l}\text { Health and environmental risks } \\
\text { (11) }\end{array}$ & Uncertain & Low \\
\hline $\begin{array}{l}\text { Entry barriers and concentration } \\
\text { (12) }\end{array}$ & High & Low \\
\hline
\end{tabular}

In particular, since genetic engineering approaches depend on knowledge outputs that are proprietary (i.e. their use is either restricted or requires payment of a licensing fee), and because novel transgenic crops are subject to harmonised regulations that are extremely expensive to comply with, domestic firms and public institutions in developing countries are very unlikely to be able to enter the transgenic seed business, even if they have the necessary technological capabilities to create relevant events. Indeed, outside of China, only large MNCs have been able to commercialise novel transgenic crop events thus far. By contrast, non-transgenic approaches depend on knowledge that may be freely available (although it too is sometimes proprietary), and regulatory hurdles are local and relatively cheap to comply with so. The entry barriers for non-transgenic approaches do not preclude seed innovation within small domestic seed firms and public institutions.

The substantial regulatory costs involved in developing new transgenic plant varieties also mean that large markets are required to recoup investments, and so transgenic innovations have been commercialised for globally produced commodity crops, and for production constraints that are either common across many countries, or in very large markets, and typically have been designed to exploit seed firms' complementarities (i.e. tolerance to proprietary herbicides). This is potentially very profitable for the few seed firms with the financial resources and global presence to develop novel transgenic traits, but there are few commercial incentives to develop new transgenic plants for local problems, crops grown at relatively small scale, or less commercial forms of agriculture. Specific local agricultural demands may thus be ignored by a genetic engineering based seed industry.

Finally, crops grown with genetically engineered seeds currently have a more restricted market that those produced using other seed technologies (in particular there is no demand for genetically engineered food crops in European markets); and genetically engineered seeds cannot be used in some agricultural systems, such as those based on agro-ecological or organic production methods. There are also a range of concerns about the potential environmental and health consequences of plant genetic engineering, which either do not exist or have not been raised in relation to other seed 
innovation techniques. These constitute an economic risk for genetically engineered seed and crop markets, over and above the regulatory costs that they entail.

In the following empirical sections, we use this multidirectional framework to explore the contribution of different seed innovation approaches to soy performance in Argentina, although in practice our distinction is between transgenic approaches and non-transgenic approaches, because data on soy seed innovation do not allow us to distinguish between cross-breeding and mutagenesis techniques. First, however, we provide brief background information about the seed sector in Argentina and we then summarise existing unidirectional analyses of the role of transgenic seed innovation in the performance of the soy sector.

\section{THE SEED SECTOR IN ARGENTINA}

Argentina is the ninth largest seed market in the world, and is the eleventh largest seed exporter. The seed market comprises three different kinds of players: MNCs, domestic companies and the state agricultural research institution, the National Institute of Agricultural Technology (INTA). Seed breeding is, at present, largely conducted by the private sector, which has an annual turnover of 772 million US dollars (ASA, 2012). MNCs gained a prominent role in the seed market in the 1990s, in the wake of the economic liberalization of the agricultural sector, and the creation of an enabling regulatory regime for transgenic seeds. Domestic firms, however, have had strong capabilities in breeding technologies for more than 70 years, and have maintained a key role, in the market, at least for some crops.

Transgenic events, developed and owned by MNCs, were approved in the late 1990s for soy, maize and cotton, and varieties containing those events subsequently released commercially, both by the owners of the transgenic sequences, and by local firms to whom the events were licensed. A glyphosate resistant event for soy, developed by Monsanto, was approved in 1996 and this was licensed to (or used freely by) ${ }^{6}$ domestic seed firms who backcrossed the sequence into local soy varieties to sell in the final market. An immediate direct effect of the glyphosate resistant soy varieties was that it lowered farmers' costs, because glyphosate was cheaper than the herbicides that farmers otherwise used, and so it diffused very rapidly; within five years almost all of the soy seeds commercialised in Argentina had incorporated the gylphosate resistant event.

Two Argentinean companies, Don Mario and Nidera, dominate the Latin American soy seed market, capturing in $201180 \%$ of the Argentinean market (see Figure 3) and between $40 \%$ and $50 \%$ of the Latin American market, with subsidiaries in Brazil, Bolivia, Uruguay, Paraguay, and more recently in the USA. Those companies gained that market share by adding Monsanto's glyphosate tolerant event to their own seed varieties, which incorporated other innovations that were demanded in the Latin American market.

\footnotetext{
${ }^{6}$ Monsanto did not obtain a patent on its glyphosate resistant trait for soya in Argentina and so other seed firms have not been obliged to pay a licensing fee to Monsanto for use of its glyphosate resistant technology although some have done so on a voluntary basis, so as to secure access to future genetic innovations (Qaim and Traxler, 2005).
} 
Figure 3: Soy seed's market: share by company (Don M ario and Nidera)

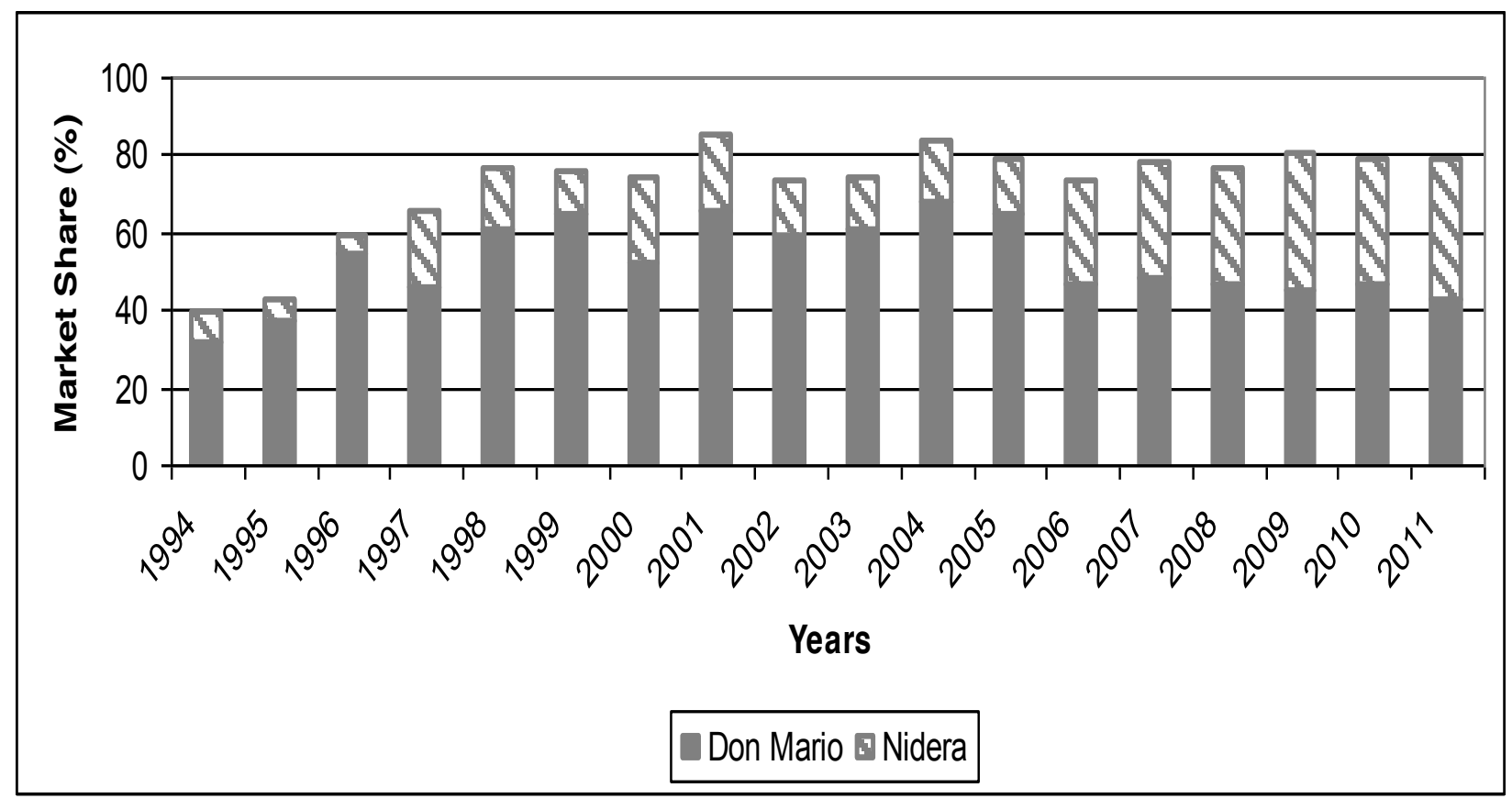

Source: Own elaboration based on data from National Seed Institute (INASE) (see Box 1 for an explanation of the data used)

Enabling regulations were key to the early commercialisation of transgenic varieties of soy, maize and cotton. A biosafety regime was set up in 1991, through which licenses for conducting field trials and eventual commercialisation could be obtained, and Argentina's patent law was reformed in 1994 to allow gene sequences with known functions, such as the novel genes introduced into transgenic seeds, to be patented.

Importantly, the extension of patent protection to the gene sequences used in transgenic varieties created asymmetric levels of protection for transgenic seeds and seeds produced using nontransgenic methods. In Argentina, as elsewhere, non-transgenic seed varieties are protected by a property rights regime for seeds based on an international protocol known, as UPOV. This gives seed breeders exclusive rights to market their own registered varieties, but allows competing plant breeders to use those registered varieties as an initial source of germplasm for the purpose of creating new plant varieties, without the need to seek permission or pay royalties to the original breeder. By contrast, the patent regime does not allow patented gene sequences to be used as a basis for further improvement to seeds without a license from their owner. This means that seed companies that have developed transgenic seed varieties have the right to a financial claim on all future seed varieties that use the transgenic gene sequence (or at least until their patent expires). By contrast firms that create a novel trait using non-transgenic techniques only have a claim on the first variety to incorporate that innovation; other firms are then free to use that non-transgenic variety (and the novel trait it incorporates) as a basis for creating their own novel seeds.

This is a huge advantage for firms that choose and are able to use a transgenic approach. This asymmetry might be justified, as a public good, if transgenic-based improvements to seeds were superior to those based on older techniques, but it is much more difficult to defend in other circumstances. In the following section we explore whether this is currently the case by analysing the 
contribution of transgenic and non-transgenic seed innovations to the performance of soy production in Argentina over the last two decades.

\section{THE ROLE OF TRANSGENIC AND NON-TRANSGENIC INNOVATIONSIN THE ARGENTINEAN SOYBEAN SECTOR: TWO PERSPECTIVES}

The performance of soy-production in Argentina, at least for certain metrics, has improved very significantly over the last two decades. Between 1990 and 2010, for example, production expanded four fold, reaching nearly fifty million tons in 2010; the area of land sown with soybean increased three fold, to nearly 19 million hectares (mainly as a result of the substitution of soy for other crops and pasture, but also because of increased double cropping with wheat), and yields increased by about 30\%, reaching a maximum of $2.9 \mathrm{~kg} / \mathrm{ha}$ in 2009 (see Figure 4). Such metrics positioned Argentina as the third soybean producing country in the world in 2010 (after the US and Brazil), the third largest exporter of soybeans, and one of the most efficient soybean producers in the world. ${ }^{7}$

\section{Figure 4: Argentinean soy production, planted area and yield evolution (1993-2011)}

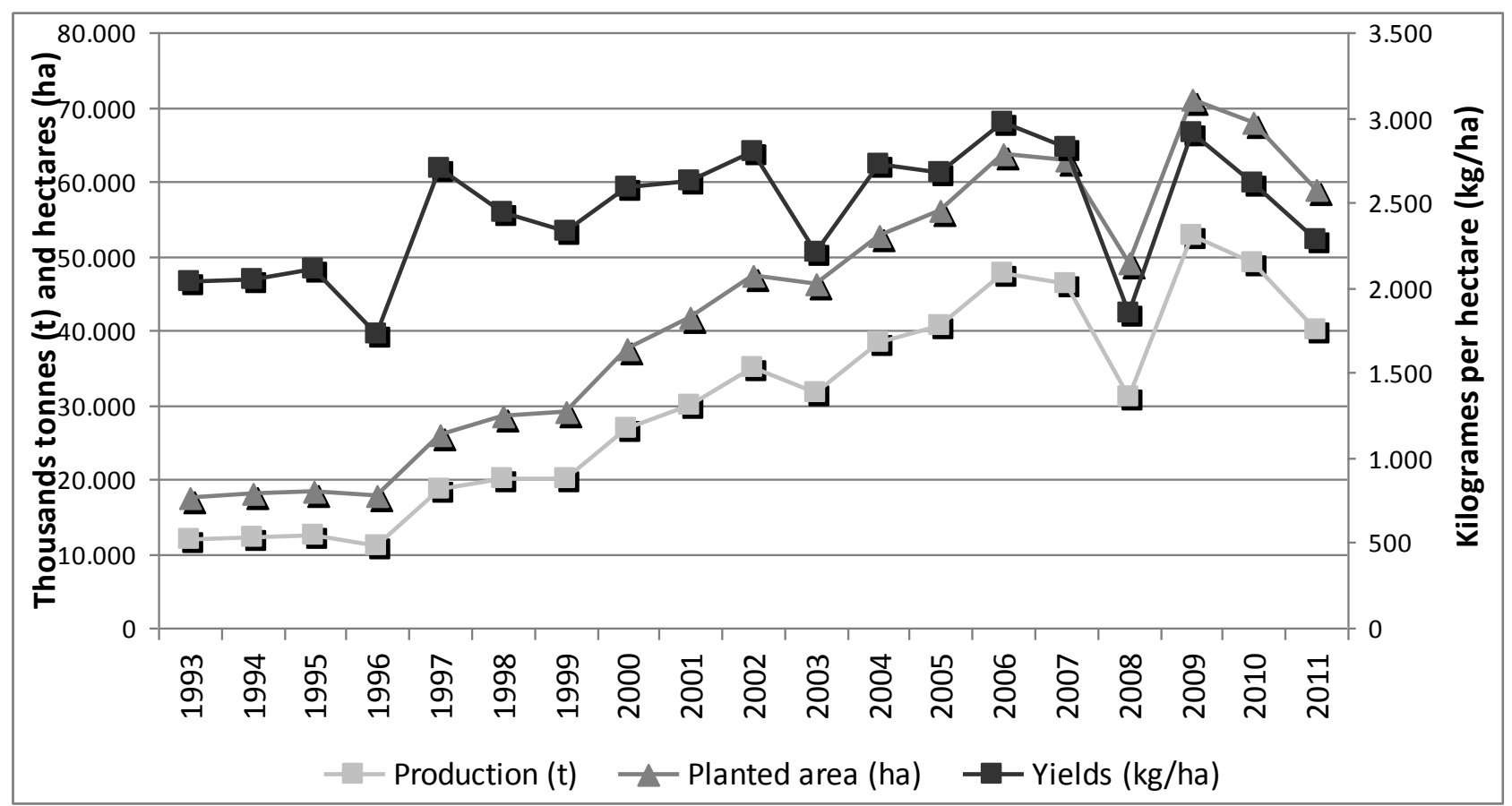

Source: Own elaboration based on data from the Ministry of Agroculture, Argentina.

In parallel with this expansion, there was a significant increase in the rate of seed innovation. Figure 5 shows the number of new soy seed varieties commercialised each year between 1982 and 2011 . We can see from both figures that the rate of innovation and the overall market expanded significantly from around 15 new varieties per year in the 1980s to around 20 in the 1990s to around 30 in the 2000s. This rise in the number of new soybean varieties offered and traded in the Argentinean

${ }^{7}$ Data from the UNCTAD database, the Argentine Institute of Statistics (INDEC) and the Argentine Ministry of Agriculture Livestock and Fisheries. 
market per year reflects the dynamic nature of innovation activity during that period. All new plant varieties commercialised have to be novel, and distinct from all other existing registered and traded varieties.

Figure 5: New soybean varieties registered in the National Registry of Property of Varieties in Argentina (1982-2011) - in numbers -

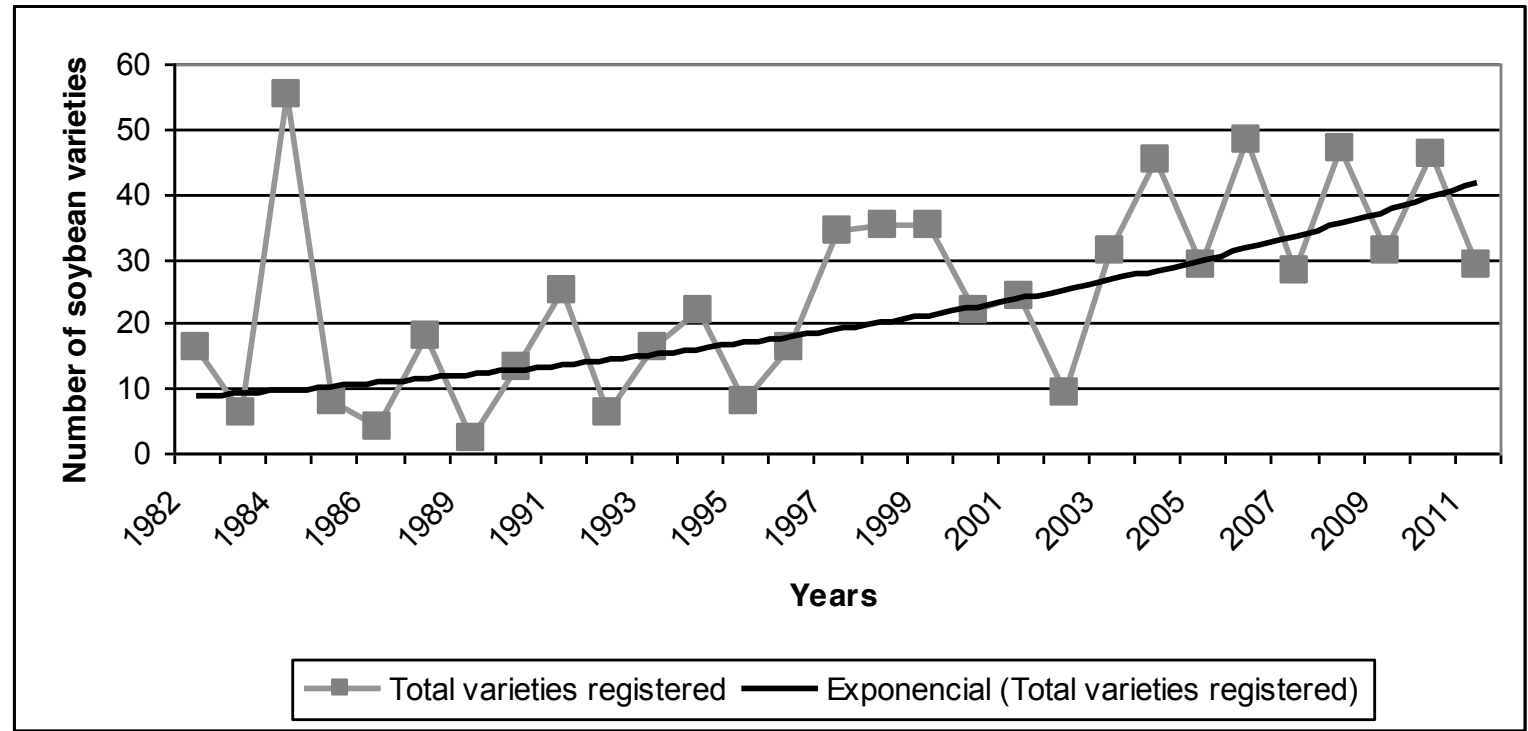

Source: Own elaboration based on the National Registry of Property of Varieties in Argentina (see Box 1 for an explanation of the data used)

\subsection{The conventional explanation: the centrality of glyphosate resistant soybean seeds}

Existing analyses of the massive expansion and competitive performance of the soy sector in Argentina have associated those changes with the diffusion of a technological package which consisted primarily of: new seeds, zero tillage practices (which involve planting seeds into unploughed land containing the residue of the previous crop), specialised agricultural machinery, herbicides, and new contracting arrangements for production. Within this package, genetically engineered soy seeds - that have a trait that confers resistance to the herbicide glyphosate - have been given a prominent, catalytic role in explaining the expansion and increased productivity of soy production, by analysts, government and the media (Bisang, 2003; Bisang 2007; Trigo, 2011, Ministerio de Economía y Producción 2004; Regúnaga et al 2003, Regúnaga 2010; Cohan; 2013). This is understood as a consequence of both the direct impact of the genetically engineered seeds in reducing farmers' production costs, and the indirect impact of the new seeds, through facilitating the diffusion of other aspects of the technological package, in particular zero tillage practices and glyphosate use which, in turn, are held to have facilitated a rise in the productivity of soy production.

The rationale for this line of argument is not particularly clear but appears to be based on:

- evidence that use of the new glyphosate tolerant seeds reduces soy production costs by about 20 US dollars per hectare (mainly as a consequence of the fact that glyphosate is cheaper than the herbicides that would otherwise need to be used)

- data on the diffusion of the glyphosate tolerant seed varieties which shows that those seeds were introduced commercially at the same time as both a) other elements of the technological package rapidly diffused (especially zero tillage practices), and b) the rate of increase in soy 
production, the area sown to soy, and double cropping of soy with wheat, all began to increase significantly

Roberto Bisang, a well-known Argentinean expert on innovation in the agricultural sector, was the first scholar to identify how a technological package, in which new seeds, practices, machinery, and agro-chemicals functioned synergistically, had driven the production and productivity boom in the commodity crop sector. In his early analysis, at least, he suggests that transgenic seeds were a key, catalytic element of that package. As he put it:

"Innovations (in the agricultural sector) began in 1996, when commercial transgenic soybean resistant to glyphosate (RR soybean) and bt corn were released for sale (Bisang, 2003). These are seeds containing a gene that becomes tolerant to glyphosate herbicide, thus (temporarily ) eliminating all competition to the transgenic plant. These allowed the massive spread of direct seeding [i.e. zero tillage], drove an increase in the demand of associated herbicides, and the application of biocide and a greater use of fertilizers. Thus, the new package, which was dormant, but that become active with the entry of the transgenic seeds, diffused as a reaction to a crisis caused by reductions in international prices and their subsequent impact on the producer." (Bisang, 2007)

Likewise, Trigo and Cap, Argentinean economists specialising in the analysis of agricultural biotechnology have argued that:

"Since the early 1990s, Argentinean grain production underwent a dramatic increase in grains production (from 26 million tons in 1988/89 to over 75 million tons in 2002/2003). Several factors contributed to this "revolution" but probably one of the most important was the introduction of new genetic modification (GM) technologies, specifically herbicide-tolerant soybeans." Trigo and Cap $(2003)^{8}$

Trigo has also argued that the introduction of transgenic seeds was a key reason for the diffusion of zero tillage practices, which, in combination with the use of glyphosate, facilitated double cropping of soy with wheat:

"The second key factor [in the explanation of the diffusion of ZT, the first being the creation of a professional association of zero tillage producers] was the introduction of GM materials. The first GM crop formally approved for commercial use was glyphosate-tolerant (GT) soybeans, in 1996. That herbicide, specifically adapted for use with zero-till technologies, facilitated the wheat-soybean double-cropping scheme" (Trigo 2009).

Trigo and Cap subsequently argued that glyphosate tolerant soy seeds have reduced farmers' direct production costs by US\$ 3.5 billion, and that an additional US\$ 62 billion of gross benefit can be attributed to genetic engineered soy on the basis that that technology aloneaccounted for the increase in the rate of the area sown to soy after the commercial introduction of the variety in 1996.

In general all such studies recognise the role played by other types of innovations in seeds, however, they are only seen as playing a supportive role; as providing background germplasm well adapted to local climatic and soil conditions into which the new glyphosate resistant trait has been inserted. Trangenesis is seen as the radical innovation (the engine of the car), and other seed innovations, as supportive of that radical change. In the words of Trigo:

\footnotetext{
8 Similar arguments can be found in Bisang, 2003; Bisang 2007; Bisang 2011; Trigo, 2011, Trigo et al 2012; Trigo and Cap, 2011; Ministerio de Agricultura, Ganadería y Pesca, 2012; Regúnaga, 2003, 2010; Cohan; 2013.
} 
"... the commercial success of GM varieties is demonstrably associated with the addition of new genes to a genetic basis agronomically well adapted to local conditions and the existence of a seed industry that could quickly and effectively bring new varieties to farmers. ... By the time that glyphosate-tolerant soybeans in Argentina were released there was an important breeding activity, in the country, both public and private, .... which allowed the new genes to be rapidly incorporated into the production cycle. From 1996 onwards a quantum leap is evidenced in the number of registered varieties..., and the bulk of the new varieties is for the GM (see figure 6)." (Trigo 2011)

\section{Figur 6: Soy seed varieties commercialized in Argentina between 1994 and 2011}

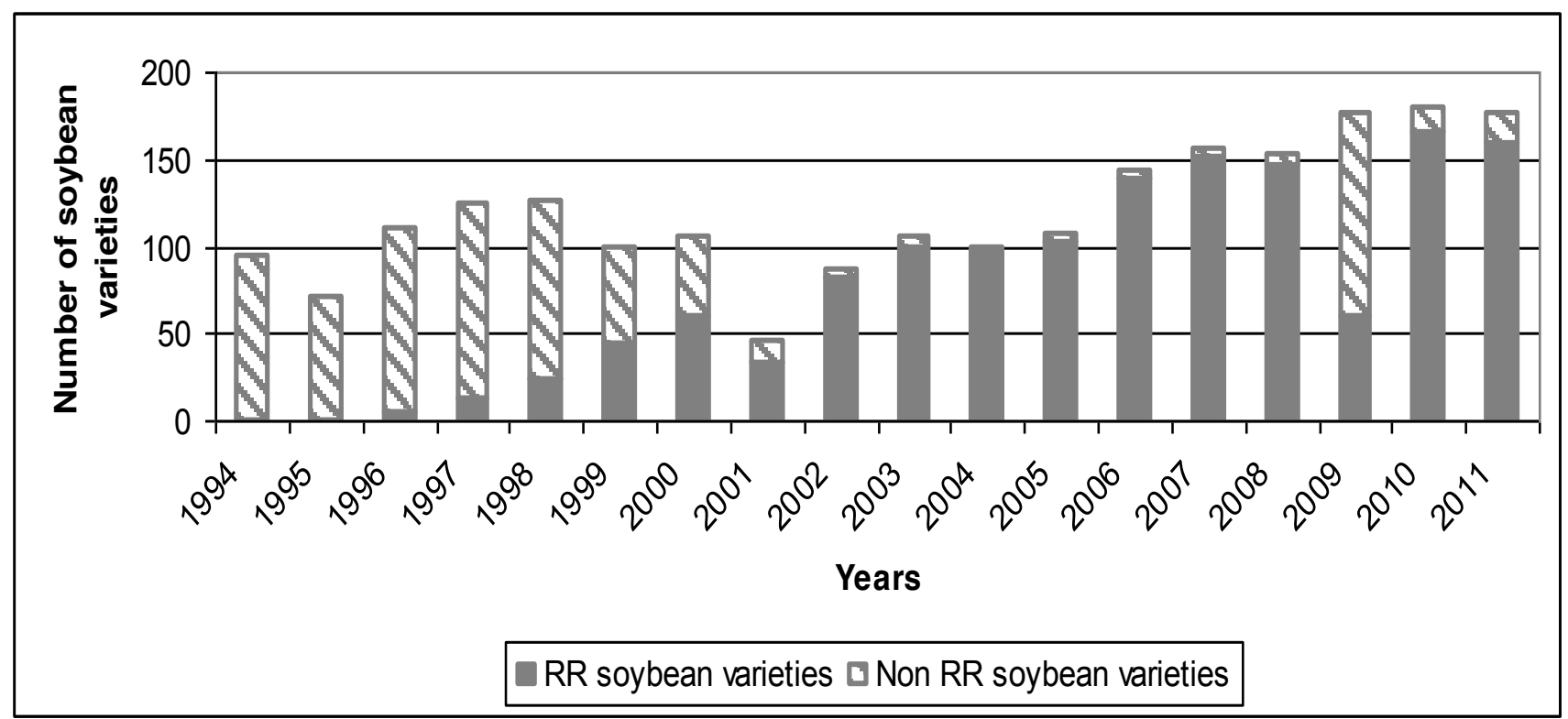

Source: Own elaboration based on data from RNPC and INASE.

The Argentinean government has often interpreted these analyses as demonstrating that transgenic seed innovations have driven the revolution in grain and oilseed production. The following excerpt from the Argentinean government's 2005-2015 strategic plan for agricultural biotechnology is not untypical. It attributes recent agricultural gains in production entirely to transgenic seed innovations, and thus emphasises the importance of sustaining this process by ensuring that domestic capabilities are developed in plant genetic engineering:

"The rapid growth of grain production in the country, due to the introduction of biotech varieties of $R R$ soybeans and Bt corn, has had an undeniable role in helping the country to mitigate the effects of economic crisis that occurred in late 2001 and early 2002. The tax on grain exports, in a context of high international prices, has allowed the national government to make available additional resources. In this way, the positive impact of biotechnology on society has been shown, albeit in a circumstantial manner, through its capacity for productive change in the generation of resources. But it is necessary to ensure the sustainability of productive growth by allocating resources to encourage innovation in new varieties." [emphasis added] (Ministerio de Economía y Producción 2004)

One problem with this widely held interpretation of what explains the increased performance and rapid growth of the soy sector in Argentina is that it tends to ignore the possible effects of many other contextual factors (e.g. increases in prices and world demand) and assumes causalities which are difficult to sustain (see Box 1 for a discussion of this point). More importantly, for our purposes, the mainstream interpretation assumes that genetic engineering has been the only significant novelty 
produced through seed innovation over the last two decades (i.e. it assumes the unidirectional view in which genetic engineering technologies represent the technological frontier of seed innovation). Improvements to seeds obtained using other technological approaches are treated as merely supportive or complementary to the radical change obtained through genetic engineering. 


\section{Box 1: The centrality of transgenic seed in Argentina's soy boom?}

Existing interpretations of why there has been a revolution in soy production in Argentina usually assume a causality that runs from the diffusion of transgenic seed from 1997 onwards to increased levels of soy production via (a) the role of transgenic seeds in accelerating the diffusion of other elements of the technological package, mainly zero tillage technologies and (b) the effects of zero tillage and other aspects of the package on both the expansion of double cropping of soy and wheat (as a consequence of the reduction in the time period between harvest of one crop and planting with another facilitated by zero tillage practices), and the expansion of new land devoted to soy production. Aside from empirical evidence of cost reductions from use of transgenic seed, this causality is difficult to sustain for the following reasons.

First, data on the diffusion of zero tillage show that diffusion of the practice began in 1990 and since then has grown at a constant rate, which did not change significantly after the introduction of GM seeds in 1997 and continued growing well after GM seeds were fully diffused (2002). Indeed some analysts have attributed the diffusion of ZT to the creation of a zero tillage association AAPRESID, in 1989, and the local development, during the 1990s, of equipment to enable direct seeding. As Derpsch, et al (2010) has noted: "The rapid growth of no-tillage in Argentina was possible because no-till seeding equipment manufacturers have responded to the increasing demand in machines". Data on the diffusion of zero tillage in Brazil, reinforce the point that the practice spread independently of the introduction of transgenic crops. By $2004,60 \%$ of the area cultivated in Brazil used zero tillage but transgenic seeds were not authorized until after 2005 (Derpsch, et al, 2010). All this suggests that although glyphosate resistant seeds might have facilitated the diffusion of zero tillage practices, they were not a necessary condition for the diffusion of this new management practice, in which case it is not justified to attribute any benefits from zero tillage to the introduction of herbicide tolerant seeds.

The causality running from transgenic seeds via zero tillage to expansion of double cropping is also complicated by the fact that data on the diffusion of double cropping suggest that this did not depend on the introduction of transgenic seeds because the period of fastest expansion of double cropping of soy and wheat was between 2003/04 and 2007/08, when transgenic soy was already fully diffused. Other seed innovations were diffusing during that time, which as will discuss in the next section can more plausibly be linked to the ability to double crop soy and wheat.

As regards the increase in the rate of expansion of land cultivated with soy, although some analysts in Argentina have linked this to the diffusion of herbicide tolerant seeds, because of the timing involved, other studies have attributed the expansion to other changes that happened before 1997 associated with changing world prices and the liberalisation of the economy that began in 1991. For example, a report from the US Department of Agriculture, linked the expansion in soy production to significant increases in soy prices prior to 1996. In that year the international prices of several crops reached historical peaks, but soy prices, at 328 US Dollars per ton, were well above wheat and corn prices at 262 and 204 US Dollars respectively. The USDA report argues that the high commodity prices incentivised an increase in the imports of other inputs, such as fertilizers, pesticides and agricultural machinery and the adoption of new technologies. (Schnepf et al, 2001). The report also linked the expansion to significant investments in infrastructure, such as the improvement of ports, which facilitated exports. In a more recent study of the expansion of cultivated land in Argentina, Lanteri (2008), from the Argentinean Central Bank, found that increases in the cultivated area between 1970 and 2006 can largely be explained as a response to relative prices. The average elasticity price for the cultivated land found in his study for all the country was between 2,37 and 5,23.

Table 2 shows that whilst the rate of growth in production, planted area and yields increased slightly in the period 1969-2002 when GM seeds diffused, the type of increase observed does not justify the idea of a "revolution" or a radical change following the introduction of GM seeds.

Table 2: Average rate of growth inter-period in production, planted area and yields(1969-2009)

\begin{tabular}{||cccc||}
\hline Years & $\begin{array}{c}\text { Growth Production } \\
\text { (aver age) }\end{array}$ & $\begin{array}{c}\text { Growth in planted area } \\
\text { (average) }\end{array}$ & $\begin{array}{c}\text { Growth in yields } \\
\text { (average) }\end{array}$ \\
\hline $1969-1973$ & 2.21 & 1.93 & 1.16 \\
$1974-1981$ & 1.52 & 1.36 & 1.07 \\
$1982-1988$ & 1.12 & 1.13 & 0.99 \\
$1989-1995$ & 1.11 & 1.04 & 1.04 \\
$1996-2002$ & 1.18 & 1.11 & 1.06 \\
$2003-2009$ & 1.10 & 1.06 & 1.04 \\
\hline
\end{tabular}

\subsection{Reinterpreting the evidence on the performance of soy production: an alternative multidirectional view}

We now re-examine this interpretation of the performance of the soy sector in ways that aim to distinguish rather than package together the improvements achieved with different technological approaches to seed innovation (i.e. assuming the multidirectional framework outlined earlier). We 
begin by re-examining data on seed innovation to try to identify the significance of non genetic engineering approaches to both seed innovation and agricultural performance. We start with a qualitative discussion of those alternative approaches, and then provide a quantitative assessment.

The numbers of new soybean varieties registered each year in Argentina since 1994 are listed in Table 3, along with the number of those new varieties that have been improved using conventional techniques only, and those that are genetically engineered varieties, containing the trait for resistance to glyphosate. Three transgenic events related to soy have been authorised in Argentina, the first in 1996 and the then two more in 2011. However, only the first of those events was commercialised before 2011, and therefore only varieties that incorporate the first event appear in our data. 


\section{Table 3 - The evolution of soybean varieties offered in the Argentinean market during the period 1994-2011}

\begin{tabular}{|lllll|}
\hline Year & $\begin{array}{l}\text { New soybean varieties } \\
\text { introduced in the } \\
\text { market } \\
\text { (i) }\end{array}$ & $\begin{array}{l}\text { Non RR soybeans } \\
\text { introduced in the } \\
\text { market } \\
\text { (ii) }\end{array}$ & $\begin{array}{l}\text { RR soybean varieties } \\
\text { introduced in the } \\
\text { market } \\
\text { (iii) }\end{array}$ & $\begin{array}{l}\text { Share of RR soy } \\
\text { beans } \\
\text { (\%) } \\
\text { (iv) }\end{array}$ \\
\hline 1995 & 12 & 12 & 0 & 0 \\
1996 & 23 & 18 & 5 & 22 \\
1997 & 24 & 16 & 8 & 33 \\
1998 & 25 & 12 & 13 & 52 \\
1999 & 30 & 10 & 20 & 67 \\
2000 & 30 & 10 & 20 & 67 \\
2001 & 1 & 1 & 0 & 0 \\
2002 & 58 & 1 & 57 & 98 \\
2003 & 37 & 4 & 33 & 89 \\
2004 & 25 & 0 & 25 & 100 \\
2005 & 13 & 1 & 12 & 92 \\
2006 & 45 & 1 & 44 & 98 \\
2007 & 26 & 0 & 26 & 100 \\
2008 & 37 & 0 & 37 & 100 \\
2009 & 98 & 44 & 54 & 55 \\
2010 & 83 & 7 & 76 & 92 \\
2011 & 34 & 5 & 29 & 85 \\
\hline
\end{tabular}

Source: Own elaboration based on data from from RNPC and INASE

We observe that since 1996, the share of transgenic varieties increased steadily, from $22 \%$ in 1998 to $100 \%$ in 2008 . The marked increase in the market share of transgenic varieties (such that the soybean seed market has in effect turned into a transgenic soybean market) nevertheless tells us little, about the importance of the trait conferring resistance to glyphosate relative to the contribution made by other approaches to seed innovation. On this issue, it is important to note that each new variety registered as a transgenic variety together with the gen that provides resistance to glyphosate has also many other genes which provide other characteristics to the seed. The novelty of the genetically engineered glyphosate resistant varieties (i.e those in the third column in table 3) thus, may be due only to the fact that the variety includes the trait that confers glyphosate-resistance, or it may be due to both the introduction of that transgenic trait and to other modifications to the plant's germplasm or only other characteristics. Seed variety registration data, nevertheless, do not allow us to make that distinction?.

\footnotetext{
${ }^{9}$ Indeed, at that time when the resistance to glyphosate was introduces there was also considerable efforst done with conventional breeding to create resistance to the disease Cancro del tallo' (see Box 3) and so some proportion of new varieties in the period 1996-98 will have involved backcrossing the trait for resistance to that disease into existing successful varieties.
} 
We can reasonably suppose, however, that in the period immediately after the transgene that confers resistance to glyphosate was released, in 1996, it is likely that the novelty of the newly registered glyphosate tolerant seeds will have to a large extent been explained by the inclusion of the gene sequence that confers resistance to glyphosate into existing soy varieties, of which there were just over 100 on the market over the two year period prior to 1996.

At some point in time most of those existing varieties would have been backcrossed with the gene sequence for glyphosate tolerance. In the five year period between 1996 and 2002 the number of new glyphosate resistant varieties matched the number of conventional varieties that had already been on the market. It is likely, therefore, that after 2002, most innovative activity in seeds would have consisted of further improvements to those soybean varieties that already contained the glyphosate resistance trait, and that non transgenic approaches explains most of the novelty captured by the over 300 new plant varieties registered and commercialised between 2003 and $2011 .^{10}$

The question is which other characteristics explain those new registrations, and how significant are they relative to the incorporation of the glyphosate tolerant trait? Registration data does not provide details of the nature of the innovative improvement to a seed variety (they only note whether a variety is genetically engineered or not). Nevertheless, based on analysis of secondary information, and interviews with key informants in the seed sector, in what follows we first describe one example of the non-transgenic innovations during the post 1997 period in Argentina and second, we perform a very simple and preliminary quantitative exercise to quantify the importance of all those nontransgenic seed innovations.

\section{(a) An example of a non-transgenic innovation: changing the growth habit of soybean varieties of long maturity groups}

Soybeans varieties belong to different maturity groups (MGs), each of which are best suited to particular latitudes. In Argentina, for example, MGs II-IV are best adapted to the Pampeana South Region; III to VI to the Pampeana North Region and, IV to IX to the North Region (as illustrated in Figure 7). One of the most important soybean innovations in Argentina (and other Latin American countries) in recent years, and one based on cross-breeding, has been to change the growth habit of soybean varieties of MGs V to VII, which work well in the Pampeana North Region and the North Region, two regions that experienced a significant increase in the cultivated area during the last decade

\footnotetext{
${ }^{10}$ In order to be registered as a new plant variety, a variety must be distinct from, all other existing registered varieties and have gained some market share. This means that once a seed contains the trait conferring resistance to glyphosate, it needs to have another characteristic of novelty to be registered
} 
Figure 7 - Argentinean soybean regions and maturity group (MG) zones

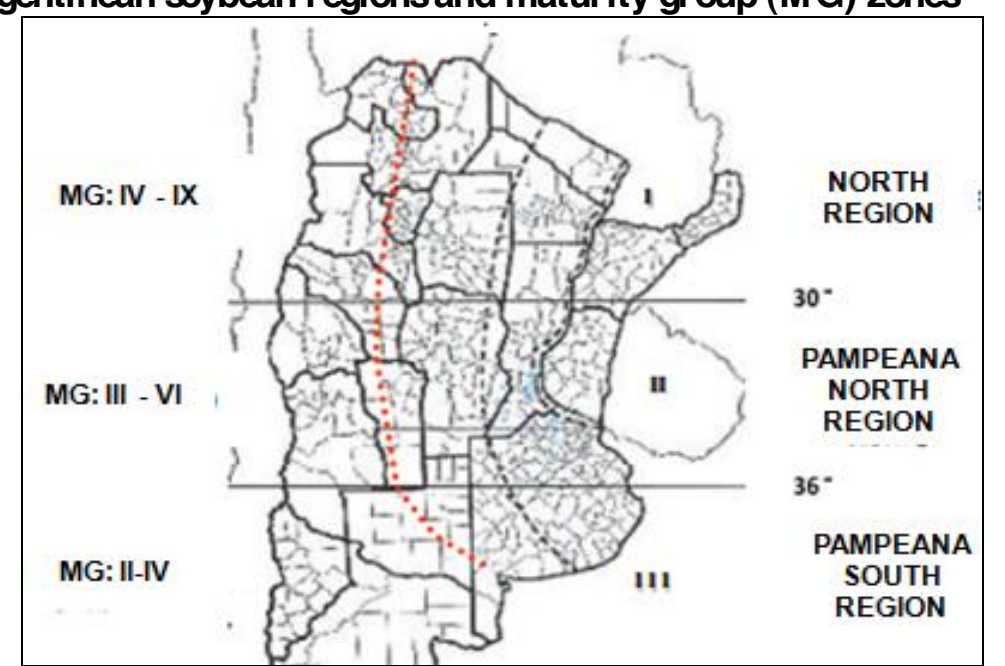

Source: Toledo, R. "Cultivo de soja" in/http://www.buscagro.com/www.buscagro.com/biblioteca/Ruben-Toledo/Elcultivo-de-soja.pdf

Soybean plants, as well as belonging to different MGs, are either determinate or indeterminate. Determinate varieties flower at a certain time of the year, when days begin to shorten, at which point vegetative growth stops and only reproductive growth (i.e. flowering and the production of fruit pods) continues. Indeterminate varieties, by contrast, continue with vegetative growth after the plant flowers and sets pods, until the weather dictates that it is time to curtail plant growth. An advantage of indeterminate soybean varieties is that they can recuperate after periods of dry weather, and so they yield better under those conditions. In addition, indeterminate varieties mature early (approximately two weeks earlier than determinate varieties) and this provides more time to plant a second crop together with soybean.

In Argentina, soybean varieties of MGs IV and below have traditionally been indeterminate whereas soybean varieties of MGs V and above have been determinate. Breeders, however, managed to create indeterminate soybean cultivars around 1997, using cross breeding techniques, for varieties within MGs V to VII. Figure 8 shows the rate of diffusion of indeterminate varieties within different MGs in the period 1997 to 2012 in Argentina. Whilst all commercialized soybean cultivars of MGs III-IV were and are indeterminate, the share of indeterminate varieties in MGs V-VII increased significantly across the whole period, from $10 \%$ in 1997 to $70 \%$ in 2011 , with the period of most rapid diffusion occurring between 2002 and 2011. 
Figure 8 - Share of indeter minate soybean varieties by type of MG in Argentina

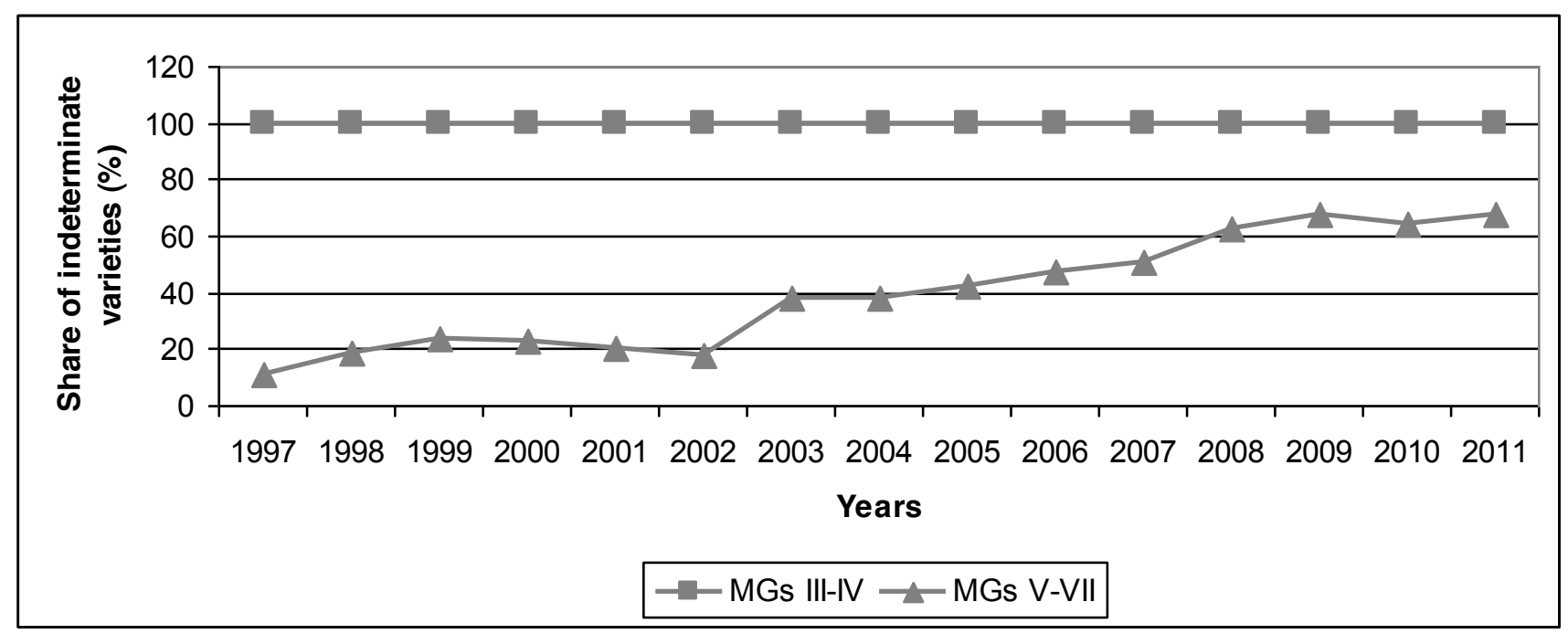

Source: Own elaboration based on Red Nacional de Evaluación de Cultivares de Soja (RECSO).

As discussed earlier, analysts in Argentina have often attributed the growth in cultivated area and production of soy (and sometimes even productivity) after 1997 to the diffusion of transgenic seeds. However, since 2001, when the gene that provides seeds with resistance to glyphosate was already fully diffused within soy varieties in Argentina, the most important phenomena we can observe was the diffusion of indeterminate varieties of high MGs, at least in the areas where varieties where high MGs work well, which are also areas that have experienced significant expansion in the area cultivated with soy, and double cropping.

It is useful to take the example of Cordoba, a province in which soy production displaced other crops and pasture such that the Province became almost exclusively a producer of soybeans during the period (2001-2011), and where varieties of MG V and VI work well. Figure 9 shows the increase in the share of both indeterminate varieties and glyphosate resistant varieties in Cordoba whilst Figure 10 shows the evolution of soy production and land cultivated with soy in the province, for the period 1997 to 2010. 


\section{Figure 9 -Diffusion of indeter minate and glyphosate resistant soybean varieties in Córdoba province (1997-2010)}

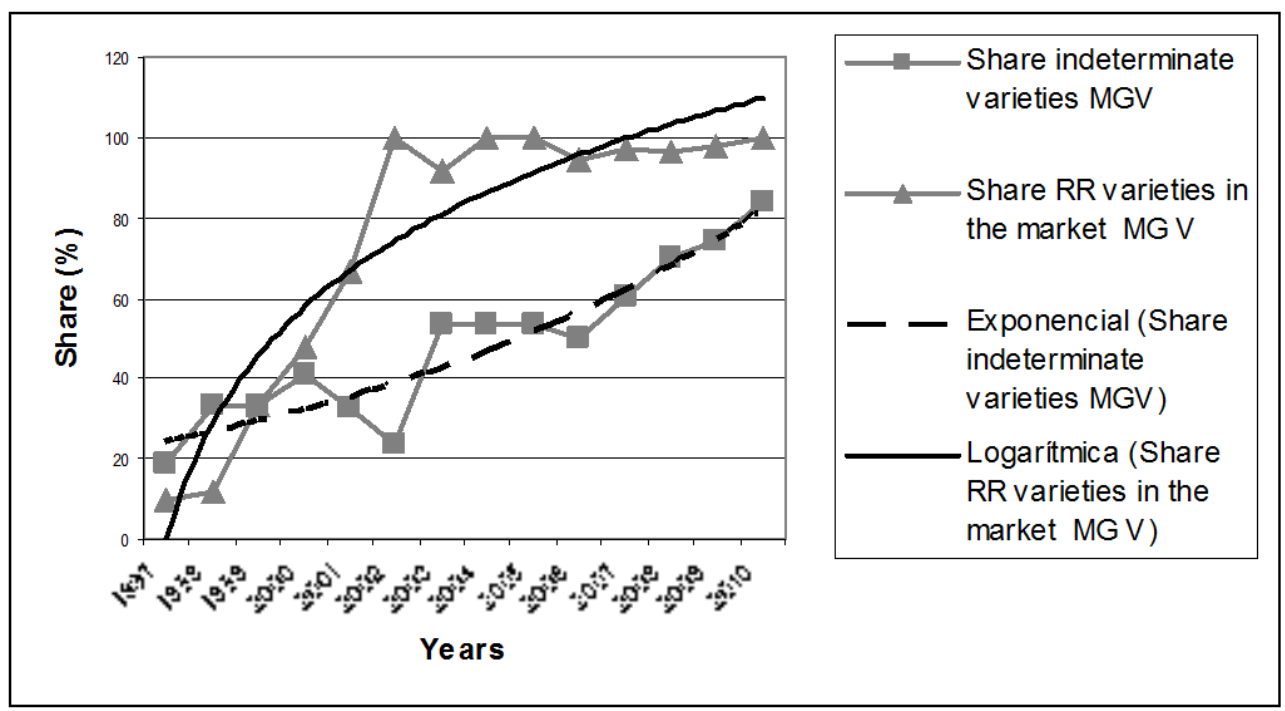

Source: Own elaboration based on Red Nacional de Evaluación de Cultivares de Soja (RECSO).

\section{Figure 10: Expansion of soy production and area cultivated with soy in Córdoba province (1997-2010)}

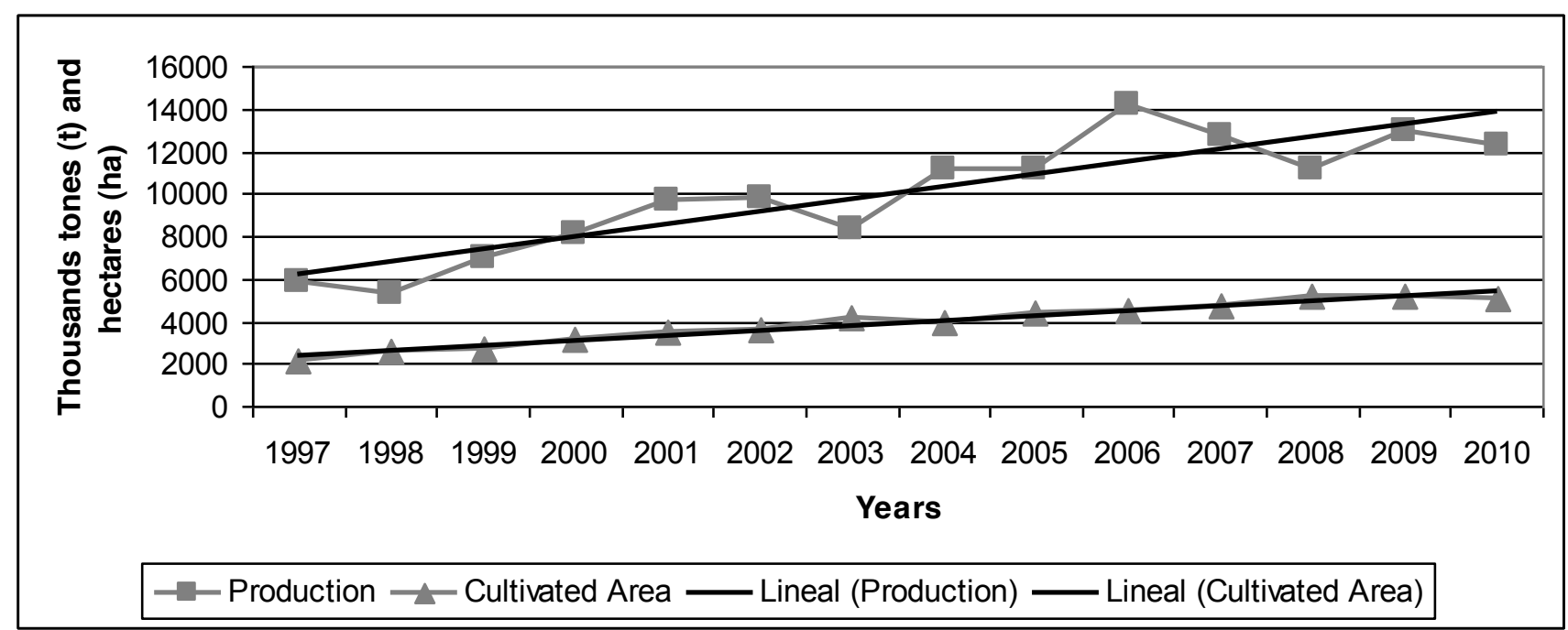

Source: Own elaboration based on Data from the Ministry of Agriculture

If we divide the periods in two, before 2002 and after 2002, then in the first period, it seems clear that the most important phenomena was the rapid diffusion of transgenic soy, but in second period, the most important was the diffusion of indeterminate varieties. Interestingly, both total soy production and the cultivated area with soy continued expanding throughout the whole period, after transgenic soy varieties had already been fully in use for some time, and in the presence of other innovations such as the diffusion of indeterminate varieties.

Table 4 shows simple correlations, contemporaneous and lagged one period, between: (a) in columns (i) and (ii) the rate of diffusion of indeterminate varieties and the increase in production, and cultivated area and, (b) in columns (iii) and (iv), the rate of diffusion of glyphosate tolerant soy and 
production and cultivated area. We divide the whole period analysed (1997-2010) in two: 1997-2002 the period of diffusion of glyphosate tolerant seeds, and 2002-2010, when the transgenic varieties was already diffused and other innovations started to diffuse. We can see in the table that while before 2002 the expansion in production and cultivated land appears more related with the diffusion of glyphosate tolerant soy, after 2002 the situation changes, the correlations are higher with the diffusion of indeterminate varieties than with the diffusion of glyphosate tolerant varieties, in both cases for contemporaneous correlations and correlations lagged one period.

Table 4: Correlations before and after 2002, contempor aneous and lagged one period.

\begin{tabular}{|c|c|c|c|c|c|}
\hline & & $\begin{array}{l}\text { Share } \\
\text { indeter minate } \\
\text { MGV } \\
\text { (i) }\end{array}$ & $\begin{array}{l}\text { Share } \\
\text { indeter minate } \\
\text { MG VI } \\
\text { (ii) }\end{array}$ & $\begin{array}{l}\text { Share RR } \\
\text { varieties } \\
\text { (GM V) } \\
\text { (iii) }\end{array}$ & $\begin{array}{l}\text { Share RR } \\
\text { varieties(GM } \\
\text { VI) } \\
\text { (iv) }\end{array}$ \\
\hline \multicolumn{6}{|l|}{ Period 1997-2002 } \\
\hline \multirow{2}{*}{ Contemporaneous } & Production & $8 \%$ & $29 \%$ & $51 \%$ & $91 \%$ \\
\hline & Cultivated Area & $31 \%$ & $20 \%$ & $-3 \%$ & $94 \%$ \\
\hline \multirow{2}{*}{ Lagged 1 period } & Production & $69 \%$ & $46 \%$ & $-18 \%$ & $89 \%$ \\
\hline & Cultivated Area & $11 \%$ & $-61 \%$ & $46 \%$ & $94 \%$ \\
\hline \multicolumn{6}{|l|}{ Period 2002/2010 } \\
\hline \multirow{2}{*}{ Contemporaneous } & Production & $39 \%$ & $46 \%$ & $30 \%$ & $27 \%$ \\
\hline & Cultivated Area & $91 \%$ & $9 \%$ & $37 \%$ & $28 \%$ \\
\hline \multirow{2}{*}{ Lagged 1 period } & Production & $67 \%$ & $40 \%$ & $-2 \%$ & $28 \%$ \\
\hline & Cultiated. Area & $67 \%$ & $40 \%$ & $-2 \%$ & $28 \%$ \\
\hline
\end{tabular}

It is therefore surprising that analysts of the Argentinean experience attribute all of the increases in both cultivated area and soy production to the diffusion of the transgenic seed innovation, when there were other seed innovations spreading at the same time, especially when we take into consideration that one of those other innovations, namely the incorporation of indetermination into certain maturity groups, appears to have just as much, or even more, potential to enable double cropping, as compared to the introduction of resistance to glyphosate. There appears to be no particular reason why years of media, professional, and policy commentary about 'GM soy' in discussions of the transformation of Argentinean soy production could not instead have been referring to 'indeterminate soy'. 


\section{Box 2: Other examples of non-transgenic innovations: disease resistance}

It is estimated that $10-15 \%$ of soybean production losses can be attributed to disease. In Argentina some of the most common local names for these diseases are Podredumbre del tallo, Podredumbre de la raíz y del tallo, Cancro del tallo and Mancha Ojo de Rana, Genetic engineering approaches have not made any contribution to resistance to those diseases; rather these have been entirely attended to by conventional cross breeding

For example, following the expansion of land cultivated to soya and favourable environmental conditions, Mancha Ojo de Rana (MOR) began to have an adverse impact on yields and seed quality (Carmona et al 2010). This disease was prevalent in the North Region, where cultivars of higher MGs are used and soybean cultivars of high MGs traded in the market had incorporated traits that provide resistance to MOR. However, between 2008 and 2010, the disease spread to other regions (specially the North Pampeana Region) where soybean cultivars (of lower MGs) had not incorporated traits that are resistant to MOR, and where, as a consequence, yields were severely affected. Since then, all cultivars of low MGs which were not MOR-resistant exited the market, and an intense breeding effort took place to develop resistant cultivars for lower MGs (Arias 2011, Sillón 2009, Formento et al 2009). The Argentinean company Don Mario was the leading firm in the development of varieties resistant to MOR and $70 \%$ of its seed portfolio is now resistant to MOR. Something similar happened with 'cancro del tallo' (CTS), a very destructive disease that caused severe damage in the years 1996-1998 (Wrather et al 2001, Ploppler 2004). Farmers faced enormous losses due to the agent Diaporthe phaseolorum var. meridionalis. Since then an intense breeding effort took place to obtain soybean varieties resistant to that disease. Other important disesases that demanded breeding efforts to develop resistant cultivars in recent years were Podredumbre de raíz y de tallo, cause dby the attack of Phytophthora sojae.

Soy varieties, resistant to such diseases, will have helped increase soy productivity by allowing for higher yields than would otherwise be the case, but no effort has been made to distinguish between these performance improvements and those that have been attributed to transgenic seed innovations.

\section{(b) Seed innovation and agricultural performance: a exploratory quantification of the benefits of non-transgenic seed innovations}

So far we have focused on the likely direct and indirect importance of one soy seed innovation that was produced using a non-transgenic approach. We now perform a very simple and preliminary quantitative exercise to quantify the direct impact of all the non-transgenic seed innovations on farmers income since 1997, and we compare this with the direct impacts of glyhosate resistance on income.

Existing studies on the direct economic effects of introducing soy varieties that are resistant to glyphosate indicate that the innovation has reduced production costs by about US\$ 20 per hectare, mainly because gylphosate is cheaper than the herbicides it has replaced (Penna and Lema 2003; Qaim and Traxler, 2005). These studies also agree that in Argentina (as in other countries) glyphosate resistance has had no overall effect on yields. Soy yields, however, increased by a total of 32\% in Argentina between 1997 and 2011 (see Figure 11), an annual average growth rate of 3\%.

Assuming constant environmental conditions, increases in yields are related to seed improvements, improvements in agronomic practices, and the combination of the two. Studies conducted in Argentina and the USA estimate that $60 \%$ of yields in soy yields gained over a period of time can be explained by genetic improvements (Santos et al 2001; Santos et al 2004; Schnepf et al, 2001; Spetch and Williams, 1984). On the basis of that estimate, and using the price obtained for soy in different periods, we can calculate the economic contribution of the genetic improvements to germplasm (which will have been obtained by cross breeding and mutagenesis), and compare this with the economic contribution of transgenic improvements in lowering costs of production. 


\section{Figure 11: Evolution of yields in soybeans: Argentina (1969-2010) (kg/ha)}

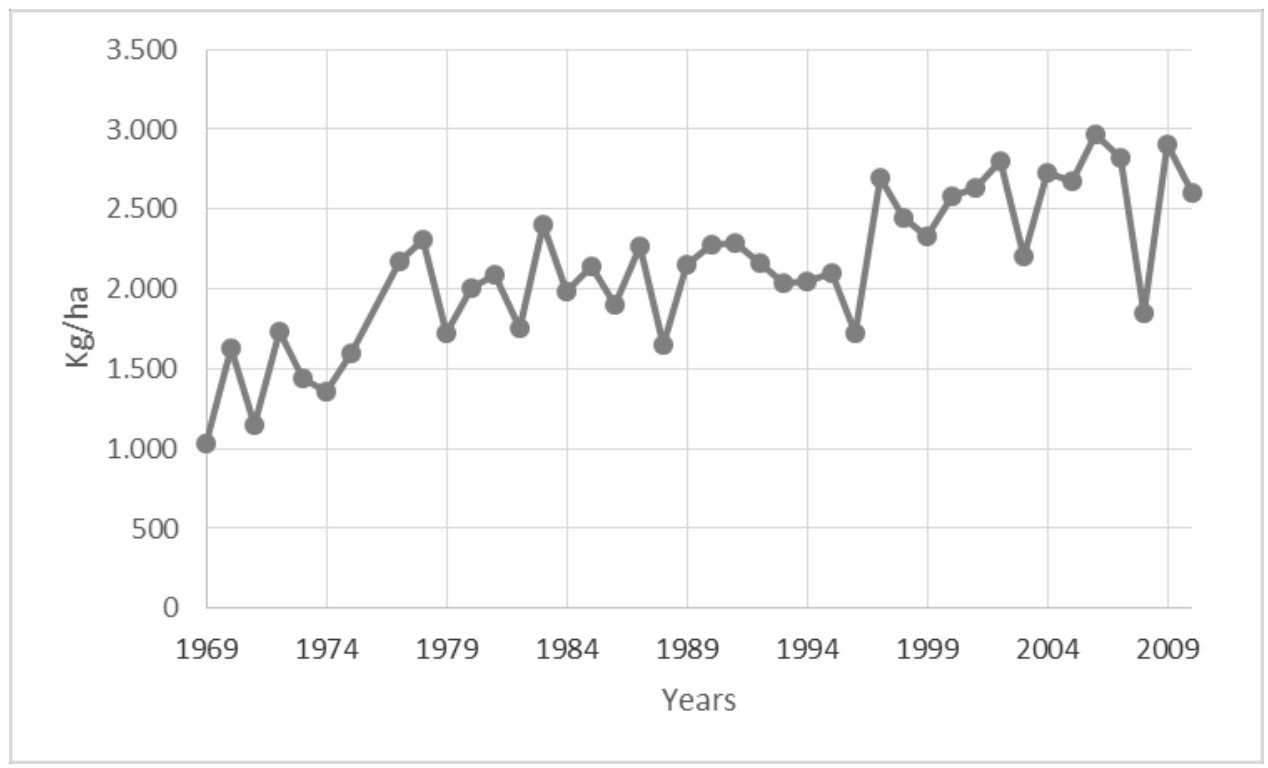

Table 5 shows average soy yields per hectare in Argentina between 1971 and 2011, grouped in periods of five years; the gains in yields over each five year period; the additional tons produced per hectare as a result of those yield increases; the dollar value of those yield gains; and the proportion of those dollar gains that can be attributed to improvements in seed germplasm, assuming a $60 \%$ contribution to yield increases from (non-transgenic) germplasm improvements.

Over the period 1997-2001, yield increases from non-transgenic improvements to germplasm imply a gain to farmers of US\$ 27.95 , as compared to a US\$ 20 reduction in costs over the same period, due to the agronomic changes in practice associated with adoption, over this period, of varieties containing the gene sequence conferring herbicide resistant

For the periods 2002-2006 and 2007-2011, we estimate a yield-related monetary gain per hectare for soy farmers of 47.53 dollars and 12.87 dollars, respectively, which again can be attributed to improvements in germplasm obtained by non-transgenic technologies. Over those two periods there would have been no further cost reductions arising from adoption of seeds containing the herbicide resistant trans-gene because glyphosate tolerant varieties were already being used by virtually all soy producers (Trigo et al, 2010). The cost savings associated with adopting glyphosate resistant varieties were a one-off.

Over the 14 year period 1997-2011, the accumulative monetary effect of gains in yields due to improvements in germplasm delivered by cross-breeding or mutagenesis is an estimated 77.16 dollars increase in income per hectare. This compares to a reduction in production costs of about 20 dollars per hectare as a result of transgenic seed innovations. In other words, about $80 \%$ of the direct gains accruing to producers as a result of seed innovation over that 14 year period can be explained by 
Table 5: Contribution of seed improvement technological approaches to agricultural performance

\begin{tabular}{|c|c|c|c|c|c|c|c|}
\hline \multirow{2}{*}{ Years } & \multirow{2}{*}{$\begin{array}{l}\text { Average productivity } \\
\text { (tons per hectare) } \\
\text { (1) }\end{array}$} & \multicolumn{3}{|l|}{ Gains } & \multicolumn{2}{|c|}{$\begin{array}{l}\text { Gains explained by germplasm improvements } \\
(60 \%)\end{array}$} & \multirow{2}{*}{$\begin{array}{l}\text { Costs reduction attributed } \\
\text { to improvements by RR } \\
\text { (dollars per hectare) } \\
\text { (7) }\end{array}$} \\
\hline & & $\begin{array}{l}\text { In yields } \\
(\%) \\
(2)\end{array}$ & $\begin{array}{l}\text { In tonnes per } \\
\text { hectare } \\
\text { (3) }\end{array}$ & $\begin{array}{l}\text { In USD per } \\
\text { hectare } \\
\text { (4) }\end{array}$ & $\begin{array}{l}\text { In yields } \\
\text { (5) }\end{array}$ & $\begin{array}{l}\text { In USD per hectare } \\
(6)\end{array}$ & \\
\hline $1971 / 72-1974 / 75$ & 1,46 & 10 & 0,130 & & 0,078 & & \\
\hline $1975 / 76-1980 / 81$ & 1,96 & 34 & 0,500 & & 0,300 & & \\
\hline $1986 / 87-1990 / 91$ & 2,05 & -1 & $-0,030$ & & $-0,018$ & & \\
\hline 1991/92-1995/96 & 2,13 & 4 & 0,080 & 19,76 & 0,048 & 11,86 & \\
\hline $1996 / 97-2000 / 01$ & 2,26 & 6 & 0,130 & 27,95 & 0,078 & 16,77 & 20,00 \\
\hline $2001 / 02-2005 / 06$ & 2,59 & 15 & 0,330 & 79,20 & 0,198 & 47,52 & \\
\hline 2006/07-2010/11 & 2,64 & 2 & 0,050 & 21,45 & 0,030 & 12,87 & \\
\hline $1996 / 2011$ & & 23 & 0,51 & 128,60 & 0,306 & 77,16 & 20,00 \\
\hline $1981 / 1996$ & & 9 & 0,17 & & 0,102 & & \\
\hline $1971 / 1981$ & & 44 & 0,630 & & 0,378 & & \\
\hline
\end{tabular}

\section{Source: Own elaboration based on data from Ministry of Agriculture.}


non-transgenic approaches to improving seeds. Furthermore, insofar as increases in the overall area sown to soya can be explained by increases in the profitability of soy production per hectare, non transgenic seed innovations will have had a much more significant indirect effect on profitability than those of transgenic improvements.

It is also worth noting that the increase in farm income as a result of the proportion of yield increases that can be attributed to non-transgenic seed innovation is qualitatively different from the cost savings that occur as a result of switching to cheaper herbicides, and that can be attributed to transgenic seed innovation. The former is an improvement that is of wider social value than the profitability and competitiveness of soy farming because it is a permanent increase in grain production per unit of land. Even if we only consider the profitability and competitiveness of soy farming, it is a benefit that is likely to endure over time. The monetary value of those yield increases will of course vary with changes in the price of soybeans, but when measured as a proportion of farmers' income from soy sales the benefit of the yield increase to soy farming is permanent. The latter cost saving, on the other hand is only of value as regards the profitability and competitiveness of soy farming and even then it may be temporary; it depends entirely on how input prices change. As Lema and Penna (2003) noted in their analysis of the adoption of transgenic soy in Argentina, if the fee for the use of the new seeds were US\$17 per hectare, as in the United States, the difference between farmers' gross margins under the transgenic and conventional systems would disappear.

\section{CONCLUSIONS}

We have argued that existing analyses of the impact of plant genetic engineering in Argentina have assumed, in effect, that genetic engineering-based innovations must be more significant that other approaches to seed innovation, because they have neglected to analyse the possible role played by improvements to soy seed using those other approaches. Our analysis, by contrast, assumed that none of the existing approaches are necessarily more or less superior to one another, and, based on this multidirectional framework, we examined the possible impacts that both transgenic and non-transgenic seed innovations may have had on the soy sector.

Both approaches to seed innovation have resulted in significant innovative outputs. Nevertheless, we argued that the direct farm-level productivity effects of seed innovations based on non-transgenic techniques, as a result of yield increases over the last twenty years, appear to be far more significant that those induced directly by genetic engineering innovations. We also illustrated, by way of an example, how a particular non-transgenic innovation, the introduction of indetermination to soy varieties belonging to certain maturity groups, is likely to have had significant effects on the performance of soy production, and, for example, provides just as plausible a contributing driver, as transgenic innovations, to the increase in double cropping of soy with other crops. Those findings contrast significantly with widely held views about the central role of seed genetic engineering in transforming the Argentinean soy sector

One implication of our analysis is that that new evidence needs to be collected to discriminate carefully between the impact of genetic engineering and other seed innovation approaches on agricultural performance. Such evidence is important because the potential consequences of mistakenly attributing gains in agricultural performance to one seed technology rather than another may have important consequence for the strategies adopted by both government and private actors in attempting to upgrade seed 
innovation capabilities. This is not only because resources and support may end up being targeted at a technological approach that may not be the best performing current option, but also because state and private support for one technological approach rather than another is likely to contribute, over time, to lock-in effects, and the crowding out of less well supported (but perhaps potentially better performing) innovation approaches. Commitments to a single technological approach may therefore become, at least to some extent, irreversible over time, even though that approach might not have been optimal in either economic or broader development terms.

Our analysis highlights more generally the importance of considering technology options when thinking about upgrading technological capabilities within industries. The (dominant) idea that technological upgrading in less advanced countries is only about selecting the right industries and then enabling a process of catching up with the already defined technological frontier within those industries, has started to be questioned recently. Our research supports new work within the innovation literature that questions this idea, and analyses the implications in a particular sector, the seed industry, in which directions of innovative change are not yet settled. Our empirical evidence has highlighted the importance of adopting this new multi-directional framework. Indeed we have shown that by failing to address questions about technological options, we end up collecting limited evidence, and conducting partial and myopic empirical analysis, and arriving at potentially misleading conclusions, which may have an substantive impact on the future evolution of an industrial sector. 


\section{REFERENCES}

Ablin, E. R., \& Paz, S. (2004). Política comercial y organismos genéticamente modificados: el mercado mundial de la soja y el caso de Argentina. In A. Bárcena, J. Katz, C. Morales \& M. Schaper (Eds.), Los transgénicos en América Latina y el Caribe: un debate abierto (pp.123-151). Santiago de Chile: Comisión Económica para América Latina y el Caribe.

Arias, N. (2011). Comportamiento de cultivares de soja a Mancha Ojo de Rana (Cercospora sojina), Este de E. Ríos, Campaña 2010/11. In INTA (Ed.) Cultivo de Soja en el Centro Este de Entre Ríos, Resultados 2010-11 (pp. 77-86).

Arundel, A. (2001). Agricultural biotechnology in the European Union: alternative technologies and economic outcomes. Technology Analysis \& Strategic Management, 13 (2), 265-279.

ASA. (2012). Retrieved from www.asa.org.ar.

Beddington, J. (2010). Food security: contributions from science to a new and greener revolution. Philosophical Transactions of the Royal Society B: Biological Sciences, 365 (1537), 61-71.

Bell, M. (2010). Innovation Capabilities and Directions of Development. (Working Paper).STEPS.

Biochemical Society (2011). Genetically modified crops, feed and food. Retrieved from http://www.biochemistry.org/LinkClick.aspx?fileticket=qf3Zm6MDTmw\%3d\&t abid=491

Bisang, R. (2003). Apertura económica, innovación y estructura productiva: La aplicación de la biotecnología en la producción agrícola pampeana argentina. Desarrollo Económico, 43(171).

Bisang, R. (2007). "Tramas productivas de alta tecnología. El caso de la soja transgénica en Argentina". En Novick, M. \& Palomino, H. (coord.) Estructura política y empleo. Un enfoque transversal. Buenos Aires: Ministerio de Trabajo Empleo y Seguridad Social.

Bisang, R. (2011). Agro y recursos naturales en la Argentina: ¿enfermedad maldita o desafío a la inteligencia colectiva?. Boletín Informativo Techint, 336, 63-83.

Brookes, G., \& Barfoot, P. (2009). Global impact of biotech crops: Income and production effects, 1996-2007. AgBioForum, 12, 184-208.

Brumlop, S., \& Finckh, M. R. (2011). Applications and potentials of marker assisted selection (MAS) in plant breeding. Bonn: Federal Agency for Nature Conservation.

Campos Motta, R. (2013). The public debate about agrobiotechnology in Latin American countries: a comparative study of Argentina, Brazil and Mexico. Serie Desarrollo Productivo, 193. Santiago de Chile: Comisión Económica para América Latina y el Caribe (CEPAL).

Cohan, L. (2013). El Aporte de la Cadena de Soja a la Economía Argentina, in press.

Commission of the European Communities (2002). Life Sciences and Biotechnology: A Strategy for Europe. Communication from the Commission to the European Parliament, the Council, the Economic and Social Committee and the committee of the Regions. Luxembourg: Office for Official Publications of the European Communities.

Derpsch, R., Friedrich, T., Kassam, A., \& Hongwen, L. (2010). Current status of adoption of non-till farming in the world and some of its main benefits, Int $J$ Agric \& Biol Eng, 3 (1), 1-25. 
Dosi, G., \& Nelson, R. R. (2009). Technical change and industrial dynamics as evolutionary processes. In Bronwyn, H. Hall \& Rosenberg, N. (Eds.) Handbook of the Economics of Innovation (51-127). North Holland.

FAO (2004). Agricultural Biotechnology: Meeting the Needs of the Poor?. Rome: FAO.

Fernie, A. R., Tadmor, Y., \& Zamir, D. (2006). Natural genetic variation for improving crop quality, Current opinion in plant biology, 9(2), 196-202.

Figueiredo, P. N. (2010). Discontinuous innovation capability accumulation in latecomer natural resource-processing firms. Technological Forecasting and Social Change, 77(7), 1090-1108.

Formento, A.N., de Souza, J., \& Zanotti, F. (2009). Comportamiento de cultivares de soja a mancha ojo de rana (Cercospora sojina) en Entre Ríos. Ciclo agrícola 2008/09. Retrieved from

http://www.inta.gov.ar/parana/info/documentos/produccion_vegetal/soja/enferm edades/20320_091209_comp.htm.

Gepts, P. (2002). A comparison between crop domestication, classical plant breeding, and genetic engineering. Crop Science, 42(6), 1780-1790.

Gutierrez, M. (2006). Concepto de variedades vegetales: la clasificación de las plantas; especies y cultivares. Definiciones y nomenclatura. El caso de las semillas híbridas. Curso Intensivo en Propiedad Industrial, Buenos Aires: Universidad de Buenos Aires.

Hobday, M. (1995). Innovation in East Asia: The Challenge to Japan. Aldershot: Edward Elgar.

Jauhar, P.P. (2006). Modern biotechnology as an integral supplement to conventional plant breeding: the aspects and challenges, Crop Science, 46 (4),1841-1859.

Jauhar, P. P. (2010). Modern biotechnology as an Integral Supplement to Conventional Plant Breeding: The Prospects and Challenges. Crop Science, 46(5), 1841-1859.

Kaplinsky, R. (2011). Schumacher meets Schumpeter: Appropriate technology below the radar. Research Policy, 40(2), 193-203.

Kemp, R., Schot, J., \& Hoogma, R. (1998). Regime shifts to sustainability through processes of niche formation: the approach of strategic niche management. Technology Analysis \& Strategic Management, 10(2), 175-198.

Kim, L. (1998). Crisis construction and organizational learning: Capability building in catching-up at Hyundai Motor. Organization science, 9(4), 506-521.

Lall, S. (1987). Learning to Industrialize: The Acquisition of Technological Capability by India. (1987), London: Macmillan Press.

anteri, L. (2008). Respuesta a precios del área sembrada de soja en la Argentina. Ensayos Económicos, 52.

Lim, C., \& Lee, K. (2001). Technological regimes, catching-up and leapfrogging: findings from the Korean industries. Research policy, 30(3), 459-483.

Marin, A., Navas-Aleman, L. \& Perez, C. (2013): Natural Resource Industries as a Platform for the Development of Knowledge Intensive Industries, Tijdschrift Voor Economische en Sociale Geografie.

McCouch, S., Baute, G. J., Bradeen, J., Bramel, P., Bretting, P.K., Buckler, E. ... \& Zamir, D. (2013). Agriculture: Feeding the future. Nature, 499(7456), 23-24.

Ministerio de Economía y Producción, Secretaría de Agricultura, Ganadería, Pesca y Alimentación de la Nación, Oficina de Biotecnología. (2004). Plan Estratégico 2005 - 2015 para el desarrollo de la biotecnología agropecuaria. Buenos Aires.

Moose, S. P., \& Mumm, R.H. (2008). Molecular plant breeding as the foundation for 21st century crop improvement. Plant physiology, 147(3), 969-977. 
Morrell, P. L., Buckler, E. S., \& Ross-Ibarra, J. (2011). Crop genomics: advances and applications. Nature Reviews Genetics, 13(2), 85-96.

Morris, M., Kaplinsky, R., \& Kaplan, D. (2011). Conceptual Overview to Understand Commodities, Linkages and Industrial Development in Africa, Paper submitted to Afreximbank November.

Penna, J. A., \& Lema, D. (2003). Adoption of herbicide tolerant soybeans in Argentina: an economic analysis. In Kalaitzandonakes, N. G. (Ed.), The Economic and Environmental Impacts of Agbiotech: a global perspective (203-221). New York: Kluwer Academic Publishers.

Perez, C. (2010). Technological dynamism and social inclusion in Latin America: a resource-based production development strategy. CEPAL Review, 100, 121-141.

Plopper, L. D. (2004). Economic importance of and control strategies for the major soybean diseases in Argentina. Proceedings from VII World Soybean Research Conference. Foz do Iguazu.

Pray, C. E., \& Naseem, A. (2007). Supplying crop biotechnology to the poor: opportunities and constraints. Journal of Development Studies, 43(1), 192-217.

Qaim, M., \& Traxler, G. (2005). Roundup Ready soybeans in Argentina: farm level and aggregate welfare effects. Agricultural Economics, 32, 73-86.

Qaim, M. (2009). The economics of genetically modified crops. Annual Review of Resource Economics, 1, 665-693.

Regúnaga, M., Fernández, S., \& Opacak, G. (2003). El impacto de los cultivos genéticamente modificados en la agricultura argentina, Programa de Agronegocios y Alimentos Facultad de Agronomía Universidad de Buenos Aires.

Royal Society, Brazilian Academy of Science, Chinese Academy of Sciences, Indian National Science Academy, Mexican Academy of Sciences \& the Third World Academy of Sciences (2000). Transgenic Plants and World Agriculture - Royal Society. Washington DC: The Royal Society.

Santos, D., Ferrari, B., Fresoli, D., Beret, P, Benavidez, R, Vicentini, R., .... \& de la Vega, A.J. (2001). Ganancia Genética en soja en Argentina entre 1980 y 2000. ACSOJA, retreived from http://www.acsoja.org.ar/images/cms/contenidos/504_b.pdf

Santos, D J., Sadras, V.O., \& Andrade, F.H. (2004). Influence of growing conditions on the expression of breeding success: the case of Argentina. Proceedings from VII World Soybean Research Conference. Foz do Iguazú.

Schnepf, R., Dohlman, E. \& Bolling, C. (2001). Agriculture in Brazil and Argentina: Developments and Prospects for Major Field Crops. Washington DC: Economic Research Service, US Departemnt of Agriculture.

Smith, A. B., Cullis, B.R., \& Thompson, R. (2005). The analysis of crop cultivar breeding and evaluation trials: a overview of current mixed model approaches. Journal of Agricultural Science, 143, 1-14.

Specht, J.E., \& Williams, J.H. (1984). Contribution of genetic technology to soybean productivity-retrospect and prospect. In W. R. Fehr, (Ed.) Genetic contributions to yield gains of five major crop plants (49-74). Madison, Wisconsin: ASA, CSSA.

Sense about Science (2009). Making Sense of GM. What is the genetic modification of plants and why are scientists doing it?. Retrieved from http://www.senseaboutscience.org/data/files/resources/9/Making-Sense-of-GMFinal-HR.pdf 
Sillón, M. (2009). Comportamiento de cultivares de soja frente a mancha ojo de rana. Red de ensayos de Agricultores Federados Argentinos Zona Norte. Ciclo agrícola 2008/09. Retrieved from

http://www.gruporomagnoli.com.ar/images/assets/ manchaojoderana.pdf.

Smith, N. (2000). Seeds of opportunity: An assessment of the benefits, safety, and oversight of plant genomics and agricultural biotechnology. Washington DC: Committee on Science, US Congress.

Smith, A., Stirling, A., \& Berkhout, F. (2005). The governance of sustainable sociotechnical transitions. Research Policy, 34(10), 1491-1510.

Trigo E., Zepeda, J. \& Falconi, C. (2009). Biotecnología Agropecuaria para el Desarrollo en América Latina: Oportunidades y Retos (Documento de Trabajo LAC, 01/010, Programa de Cooperación BID/FAO).

Trigo, E. (2011). Fifteen years of genetically modified crops in Argentine agriculture. Buenos Aires: Argentine Council for Information and Development of Biotechnology. Trigo, E., \& Cap, E. J. (2003). The impact of introduction of transgenic crops in Argentinean agriculture. AgBioForum, 6(3), 73-90.

Trigo, E., Falck-Zepeda, J., \& Falconi, Z.C. (2010). Biotecnología agropecuaria para el desarrollo en América Latina: Oportunidades y retos. Washington DC: InterAmerican Development Bank.

Uctu, R. \& Essop, H. (2013). The role of government in developing the biotechnology industry: a South African perspective. Prometheus, 31(1), 21-33.

United Nations Development Program (2001). Making New Technologies Work for Human Development. Oxford: O. U. Press.

Wrather, J.A., Anderson, T.R., Arsyad, D.M., Tan, Y., Ploper, L.D., Porta-Puglia, A., Ram, H.H., \& Yorinori, J.T. (2001). Soybean disease loss estimates for the top ten soybean producing countries in 1998. Canadian Journal of Plant Pathology, 23, 115-121.

Zamir, D. (2008). Plant breeders go back to nature. Nature Genetics, 40(3), 269-270. 


\title{
Recent papers in the SPRU Working Paper Series:
}

SWPS 2014-01. Nicola Grassano and Maria Savona. January 2014. "Productivity in services twenty years on. A review of conceptual and measurement issues and a way forward".

SWPS 2014-02. Florian Kern, Adrian Smith, Chris Shaw, Rob Raven and Bram Verhees. February 2014. "From laggard to leader: Explaining offshore wind developments in the UK."

SWPS 2014-03. Andy Stirling. March 2014. "Transforming Power: social science and the politics of energy choices."

SWPS 2014-04. Alex Coad, Gabriele Pellegrino and Maria Savona. March 2014. "Don't Stop Me Now: Barriers to innovation and firm productivity."

SWPS 2014-05. Antonio Messeni Petruzzelli, Vito Albino, and Daniele Rotolo. April 2014. "Determinants of Patent Citations in Biotechnology: An Analysis of Patent Influence Across the Industrial and Organizational Boundaries."

SWPS 2014-06. Andy Stirling. April 2014. "From Sustainability to Transformation: Dynamics and diversity in reflexive governance of vulnerability."

SWPS 2014-07. Ralitsa Petrova Hiteva and Tomas Maltby. April 2014. "Standing in the way by standing in the middle: the case of state-owned natural gas intermediaries in Bulgaria."

SWPS 2014-08. Sabine Hielscher and Adrian Smith. May 2014. "Community-based digital fabrication workshops: A review of the research literature."

SWPS 2014-09. José García-Quevedo, Gabriele Pellegrino and Maria Savona. May 2014. "Reviving demand-pull perspectives: The effect of demand uncertainty and stagnancy on R\&D strategy."

SWPS 2014-10. Daniele Rotolo, Ismael Rafols, Michael Hopkins, and Loet Leydesdorff. June 2014. "Scientometric Mapping as a Strategic Intelligence Tool for the Governance of Emerging Technologies."

SWPS 2014-11. Andy Stirling and Josie Coburn. June 2014. “Multicriteria Mapping Manual Version 1.0."

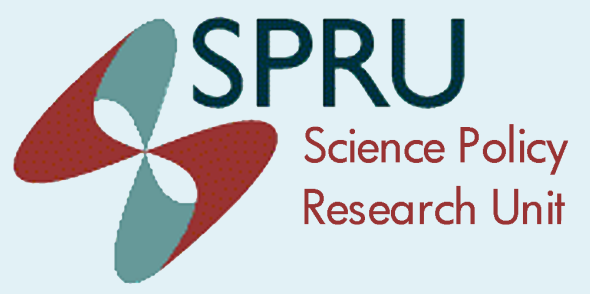

\author{
SPRU \\ Science Policy Research Unit \\ University of Sussex \\ Falmer, Brighton, BN1 9SL, UK \\ www.sussex.ac.uk/spru
}

